\title{
COMPARATIVE STUDY ON THE EFFECT OF NITRIC OXIDE, CHROMIUM AND EDTA ON OXIDATIVE STRESS RESPONSES IN AGATHI (SESBANIA GRANDIFLORA L. PERS)
}

\author{
REVATHI, S. ${ }^{1}-$ SUBHASHREE, V. ${ }^{2 *}$ \\ ${ }^{1}$ Bannari Amman Institute of Technology, Sathyamangalam, Erode, Tamil Nadu, India \\ (phone: +91-42-9522-6000; fax: +91-42-9522-6666) \\ ${ }^{2}$ School of Bio Sciences and Technology, VIT University, Vellore, Tamil Nadu, India \\ (phone: +91-41-6224-3091; fax: +91-41-6224-3092) \\ *Corresponding author \\ e-mail:v_subhashree@hotmail.com; phone: +91-94-8694-7377
}

(Received 23 $3^{\text {rd }}$ Nov 2018; accepted 28 $8^{\text {th }}$ Jan 2019)

\begin{abstract}
Heavy metal contaminations are a major cause of global environmental pollutions. The release of heavy metals into the environment has increased the threat of serious health issues for living organism. Among the known heavy metals, chromium is released into the environment by various anthropogenic activities causing various ill effects on the life forms. Hence in the present study which was carried out in Vellore Institute of Technology, Tamil Nadu, India and the phytoextraction of chromium enhanced with metal chelator ethylenediamine tetraacetic acid was studied in Sesbania grandiflora in VIT, India. To asses this, various treatments were prepared with combinations of chromium and chelator. The antioxidant enzyme activities such as Superoxide dismutase, Catalase, Ascorbate peroxidase and Glutathione reductase activity were determined in the presence of metal and chelator. The results showed an increase in all the antioxidant enzymes in the presence of metal and chelator due to the increased metal uptake. To reduce the stress levels created by the metal and chelator, sodium nitroprusside a nitric oxide donor was exogenously sprayed on to the plants and a comparative study was made in the presence and absence of sodium nitroprusside. The results indicated that the presence of sodium nitroprusside had a positive role in combating the stress created by the metal and chelator which was evident by the reduced antioxidant enzyme levels in spite of metal uptake. Hence sodium nitroprusside could be considered for its wider application against metal stress conditions to combat oxidative stress. The plant Sesbania grandiflora showed higher withstanding capacity to the heavy metal stress and was effective in extracting the metal out of the contaminated soil.
\end{abstract}

Keywords: heavy metal, Sesbania grandiflora, superoxide dismutase, catalase, sodium nitroprusside, chelator, oxidative stress

\section{Introduction}

Heavy metals pose a critical concern to human health due to their increasing usage as industrial inputs (Alloway, 1995; Diels et al., 2002). Chromium (Cr) is an environmental pollutant that ranks seventh in abundance in the earth crust. The major contributors of $\mathrm{Cr}$ contamination are the leather tanning, electroplating, and stainless steel industries. India is one of the largest producers of leather, and nearly $80 \%$ of the tanneries are engaged in the chrome-tanning process. Chromium being toxic interferes with metabolic processes in plants, which causes several morphological and physiological changes causing reduced growth, impaired photosynthesis and can lead to death of the plant. Chromium exists in two forms $\mathrm{Cr}$ (III) and $\mathrm{Cr}$ (VI). Among them $\mathrm{Cr}$ (VI) exists in the forms of chromate anions $\left(\mathrm{CrO}_{4}^{-2}\right)$, dichromate $\left(\mathrm{Cr}_{2} \mathrm{O}_{7}{ }^{2-}\right)$ and chromium trioxide $\left(\mathrm{CrO}_{3}\right)$ which are considered the most toxic forms of chromium, since they possess high oxidizing potential, high solubility, and mobility across the 
membranes in living organisms and in the environment (Azmat and Khanum, 2005). Clean up of contaminated soils needs special attention because these soils support agricultural crops and so the consumption of crop plants grown on these soils may create serious health hazards.

Plants sequester heavy metals in roots and/or shoots and, therefore, significantly contribute to metal removal from the environment through the mechanism of phytoremediation (Jadia and Fulekar, 2009). The uptake and translocation of such heavy metal by plants can be made bio available by the addition of natural or synthetic chelators (Schmidt, 2003; Quartacci et al., 2006) like, ethylenediamine tetraacetic acid (EDTA), ethylenediamine di (o-hyroxyphenylacetic acid) (EDDHA) and hydroxyethylethylene-diaminetriacetic acid (HEDTA). Among them, EDTA is most effective chelating agent which enhances the accumulation of metals, by mobilizing metal cations, water soluble complexes (Lestan et al., 2008) there by modifying the availability of the metals in soils to the above ground parts of plants (Garba et al., $2012 \mathrm{~b}$ ), and increasing the uptake of heavy metals.

One of the mechanisms that make a plant tolerant to heavy metal stress is the presence of strong antioxidant defense system (Metwally et al., 2005; Qureshi et al., 2005; Israr et al., 2006 and Diwan et al., 2008). Heavy metals stress causes molecular damage to plants, either directly or indirectly through reactive oxygen species (ROS) formation. Further, plants growing in chromium-stressed environment suffer due to potential risk from reactive oxygen species (ROS) like superoxide $\left(\mathrm{O}_{2}{ }^{\cdot-}\right)$, hydroxyl radicals $(\bullet \mathrm{OH})$ and hydrogen peroxide $\left(\mathrm{H}_{2} \mathrm{O}_{2}\right)$. However, plants possess their own defense system to combat these toxicity problems like cellular antioxidants and antioxidant enzymes that play a vital role in protecting the plant from various physiological damage caused by ROS (Mittler, 2002., Baek and Skinner, 2003) that make a plant species tolerant to heavy metal stress (Metwally et al., 2005; Qureshi et al., 2007; Israr et al., 2006; Diwan et al., 2008). Antioxidant system consists of enzymatic and non-enzymatic compounds. Enzymatic antioxidants include superoxide dismutase, catalase, peroxidases, glutathione reductase and ascorbate reductase. Non-enzymatic antioxidants are ascorbate, glutathione, tocopherol and carotenoids (Mittler, 2002; Candan and Tarhan, 2003).

Nitrite oxide (NO) is a lipophilic molecule that diffuses through membranes. Although first described as a signal molecule in animals, accumulating evidence shows that NO is an important signal molecule involved in plant response to biotic and abiotic stresses (Delledonne et al., 1998; Carlos and Lorenzo, 2001; Uchida et al., 2002).

Based on the above observation, the objective of the present study is to investigate whether exogenous sodium nitroprusside (SNP) plays a positive role in protecting Sesbania grandiflora against antioxidative stress created by chromium in the presence of EDTA.

\section{Materials and methods}

\section{Soil spiking and experimental setup}

The study was done in Vellore Institute of Technology (VIT), Tamil Nadu, India. The experiments were conducted during the months of June-August. Pot experiments were conducted using the soil samples taken from VIT garden. The soil was air-dried and sieved. The study was a comparison made by conducting two experiments (Exp), namely Exp 1 and Exp 2. Five pots each containing $2.7 \mathrm{~kg}$ of soil $+0.3 \mathrm{~kg}$ of manure 
was mixed along with five different concentrations of chromium and ethylenediamine tetraacetic acid (EDTA) in case of Exp 1. The study was done to assess the efficiency of chromium accumulation by Sesbania grandiflora. This was studied in comparison with Exp 2 containing in addition $10 \mathrm{ml}$ of $250 \mu \mathrm{M}$ of SNP as foliar spray along with chromium and EDTA. The various treatments that were considered in Exp 1 and Exp 2 are given in the following treatment tables:

\begin{tabular}{c|c}
\hline Treatment name (Exp 1) & Concentrations \\
\hline $\mathrm{C} 1$ & $20 \mathrm{mg} \mathrm{Cr} \mathrm{Kg}^{-1}$ \\
\hline $\mathrm{C} 2$ & $40 \mathrm{mg} \mathrm{Cr} \mathrm{Kg}^{-1}$ \\
\hline $\mathrm{C} 3$ & $60 \mathrm{mg} \mathrm{Cr} \mathrm{Kg}^{-1}$ \\
\hline $\mathrm{C} 4$ & $80 \mathrm{mg} \mathrm{Cr} \mathrm{Kg}$ \\
\hline $\mathrm{C} 5$ & $100 \mathrm{mg} \mathrm{Cr} \mathrm{Kg}$ \\
\hline $\mathrm{C} 1+$ EDTA & $20 \mathrm{mg} \mathrm{Cr} \mathrm{Kg}+0.35 \mathrm{mM} \mathrm{EDTA}$ \\
\hline $\mathrm{C}$ +EDTA & $40 \mathrm{mg} \mathrm{Cr} \mathrm{Kg}+0.35 \mathrm{mM} \mathrm{EDTA}$ \\
\hline $\mathrm{C} 3+$ EDTA & $60 \mathrm{mg} \mathrm{Cr} \mathrm{Kg}+0.35 \mathrm{mM}$ EDTA \\
\hline C4+EDTA & $80 \mathrm{mg} \mathrm{Cr} \mathrm{Kg}+0.35 \mathrm{mM} \mathrm{EDTA}$ \\
\hline C5+EDTA & $100 \mathrm{mg} \mathrm{Cr} \mathrm{Kg}+0.35 \mathrm{mM} \mathrm{EDTA}$ \\
\hline
\end{tabular}

\begin{tabular}{c|c}
\hline Treatment Name (Exp2) & Concentrations \\
\hline C1 & $60 \mathrm{mg} \mathrm{Cr} \mathrm{Kg}^{-1}$ \\
\hline $\mathrm{C} 2$ & $100 \mathrm{mg} \mathrm{Cr} \mathrm{Kg}^{-1}$ \\
\hline $\mathrm{C} 3$ & $60 \mathrm{mg} \mathrm{Cr} \mathrm{Kg}^{-1}+0.35 \mathrm{mM} \mathrm{EDTA}$ \\
\hline $\mathrm{C} 4$ & $100 \mathrm{mg} \mathrm{Cr} \mathrm{Kg}+0.35 \mathrm{mM} \mathrm{EDTA}$ \\
\hline $\mathrm{C} 5$ & $60 \mathrm{mg} \mathrm{Cr} \mathrm{Kg}+250 \mu \mathrm{M} \mathrm{SNP}$ \\
\hline $\mathrm{C} 6$ & $100 \mathrm{mg} \mathrm{Cr} \mathrm{Kg}^{-1}+250 \mu \mathrm{M} \mathrm{SNP}$ \\
\hline $\mathrm{C} 7$ & $60 \mathrm{mg} \mathrm{Cr} \mathrm{Kg}^{-1}+0.35 \mathrm{mM} \mathrm{EDTA}+250 \mu \mathrm{M} \mathrm{SNP}$ \\
\hline $\mathrm{C} 8$ & $100 \mathrm{mg} \mathrm{Cr} \mathrm{Kg}$ \\
\hline $\mathrm{C} 9$ & $\mathrm{Control}+250 \mu \mathrm{mM} \mathrm{EDTA}+250 \mu \mathrm{M}$ SNP \\
\hline $\mathrm{C} 10$ & Control
\end{tabular}

Control plants were free of chromium and EDTA (Exp 1) and contained SNP in case of Exp 2. All the treatments were done in triplicates. The control and the treated soil were left to equilibrate for 3 weeks during which it was occasionally turned and mixed to ensure thorough mixing. The seeds of Sesbania grandiflora were sterilized in $3 \%$ formaldehyde and sown in plastic trays for one week to attain the seedling stage (Fig. 1a). About 6 seedlings were transferred to the spiked soil pots after three weeks of incubation. Totally 33 pots from Exp 1 and Exp 2 were maintained in a randomized block design (Fig. 1b). Both the experiments were performed at the same time period. The harvested plants were collected during every morning at the end of 30,60 and 90 days and were stored at $-20{ }^{\circ} \mathrm{C}$ for a short duration and all the enzyme assays were performed within a week's time from the harvest.

\section{Enzyme extraction and activity of antioxidant enzymes}

$500 \mathrm{mg}$ of fresh leaves was weighed and homogenized in $3 \mathrm{ml}$ of extraction buffer containing $0.5 \mathrm{ml}$ of $50 \mathrm{mM}$ potassium phosphate buffer ( $\mathrm{pH} 7.5$ ), $0.5 \mathrm{ml}$ of Triton $\mathrm{X}$ $100,1 \mathrm{~g}$ of polyvinyl pyruvate (PVP) and $3.72 \mathrm{mg}$ of EDTA. The homogenate were 
filtered and centrifuged at $15,000 \times \mathrm{g}$ for $20 \mathrm{~min}$ at $4{ }^{\circ} \mathrm{C}$. The supernatant was used for assaying superoxide dismutase (SOD), ascorbate peroxidise (APX) and glutathione reductase $(\mathrm{GR})$ activities.

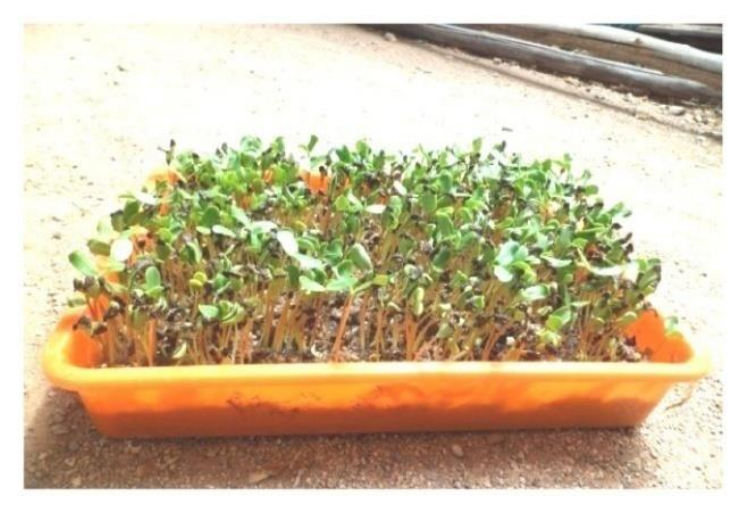

a

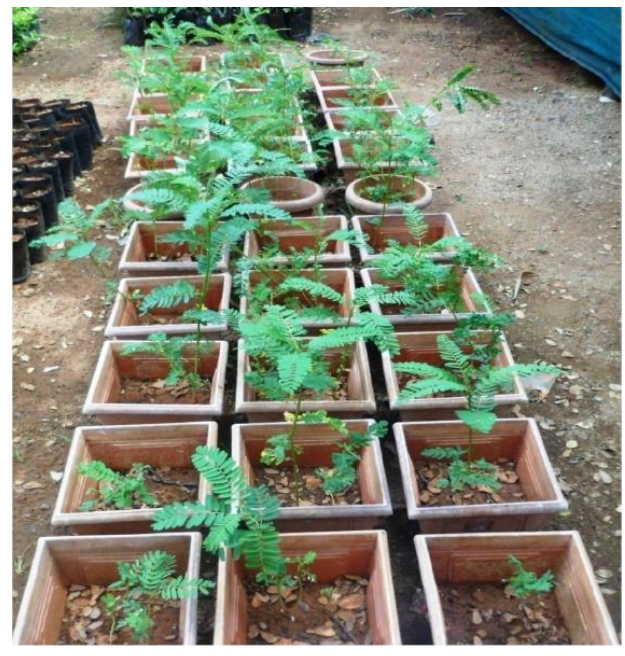

b

Figure 1. a One week old seedling of Sesbania grandiflora; $\boldsymbol{b}$ randomized block design of treatment pots

\section{Superoxide dismutase (SOD) (EC1.15.1.1)}

SOD activity was assayed using a modified NBT method according to Beyer and Fridovich (1987). The $2 \mathrm{ml}$ assay reaction mixture contained $50 \mathrm{mM}$ phosphate buffer (pH 7.8) containing $2 \mathrm{mM}$ EDTA, $9.9 \mathrm{mM}$ L-methionine, $55 \mu \mathrm{M}$ nitro blue tetrazolium (NBT), and $0.025 \%$ Triton-X100. $40 \mu \mathrm{l}$ of diluted $(2 \times)$ sample and $20 \mu \mathrm{l}$ of $1 \mathrm{mM}$ riboflavin were added and the reaction was initiated by illuminating the samples under a $15 \mathrm{~W}$ fluorescent tube. Duplicate tubes with the same reaction mixture were kept in the dark and used as blank. Absorbance of the samples was measured immediately after the reaction was stopped at $560 \mathrm{~nm}$ against blank. The enzyme activity grams ${ }^{-1} \mathrm{f} . \mathrm{w}$ of a sample was determined from a standard curve obtained by using pure SOD.

Native polyacrylamide gel electrophoresis (PAGE) of crude extract (25 $\mu \mathrm{g})$ combined with loading buffer (containing neither SDS nor P-mercaptoethanol) was performed in a mini-gel system (Medox) at 150-200 V. SOD activity in native polyacrylamide gels was determined by the nitroblue tetrazolium (NBT) method of Beauchamp and Fridovich (1971). SOD activity was visible after several minutes as an achromatic band against a blue background.

\section{Catalase (CAT) (EC 1.11.1.6)}

The Catalase assay was performed by the method of (Luck, 1974). The enzyme extract $(0.02 \mathrm{ml})$ was added to the reaction mixture containing $3 \mathrm{ml}$ of hydrogen peroxide $\left(\mathrm{H}_{2} \mathrm{O}_{2}\right)$ and $0.067 \mathrm{M}$ phosphate buffer ( $\mathrm{pH}$ 7.0) and the optical density change was measured at $240 \mathrm{~nm}$, the time taken for decrease in the absorbance from 0.45 to 0.4 is noted as $\Delta \mathrm{T}$. The activity of the enzyme is expressed in the terms of $\mu$ mole of $\mathrm{H}_{2} \mathrm{O}_{2}$ consumed/min/ mg protein. The activity was determined by calculating the concentration of $\mathrm{H}_{2} \mathrm{O}_{2}$ using the extinction coefficient 0.036 per $\mu$ mole per $\mathrm{ml}$. 


\section{Ascorbate peroxidase (APX) (EC1.11.1.11)}

The APX activity was determined by the method followed by Nakano and Asada (1987). The $1 \mathrm{ml}$ reaction mixture contained $0.1 \mathrm{ml}$ of $100 \mathrm{mM}$ potassium phosphate buffer ( $\mathrm{pH} 7.0$ ), $0.5 \mathrm{mM}$ ascorbate, $0.3 \mathrm{mM} \mathrm{H}_{2} \mathrm{O}_{2}$ and $50 \mu \mathrm{l}$ of enzyme extract. The oxidation of ascorbic acid was measured by the decrease in absorbance at $290 \mathrm{~nm}$ for 3 min using a spectrophotometer. The enzyme activity was calculated using the extinction coefficient $2.8 \mathrm{mM}^{-1} \mathrm{~cm}^{-1}$ and expressed in enzyme units (mg protein) $)^{-1}$. One unit of enzyme is the amount necessary to decompose $1 \mu \mathrm{mol}$ of substrate per min at $25^{\circ} \mathrm{C}$.

\section{Glutathione reductase (GR) (EC 1.6.4.2)}

The activity of GR was measured by monitoring the glutathione dependent oxidation of (Nicotinamide adenine dinucleotide phosphate) NADPH described by Rao et al. (1996). $1 \mathrm{ml}$ reaction mixture contained $0.1 \mathrm{ml}$ of $100 \mathrm{mM}$ potassium phosphate buffer (pH 7.5), $0.1 \mathrm{ml}$ of $1 \mathrm{mM}$ EDTA, $0.02 \mathrm{ml}$ of $0.2 \mathrm{mM} \mathrm{NADPH}, 0.05 \mathrm{ml}$ of $0.5 \mathrm{mM}$ oxidized glutathione and $50 \mu \mathrm{L}$ of enzyme extract. The reaction was allowed to run for $3 \mathrm{~min}$ and the absorbance was measured at $340 \mathrm{~nm}$ using a spectrophotometer. The enzyme activity was calculated using extinction coefficient $6.2 \mathrm{mM}^{-1} \mathrm{~cm}^{-1}$ and expressed in enzyme units $\left(\mathrm{mg}_{\text {protein }}^{-1}\right)$. One unit of enzyme is the amount necessary to decompose $1 \mu \mathrm{mol}$ of NADPH per min at $25^{\circ} \mathrm{C}$.

\section{Determination of ascorbate oxidase activity $(A A O)(E C$ 1.10.3.3)}

Assay of ascorbic acid oxidase activity was carried out according to Oberbacher and Vines (1963). $0.1 \mathrm{ml}$ of the enzyme extract was added to $3 \mathrm{ml}$ of the substrate solution (8.8 $\mathrm{mg}$ of ascorbic acid in $300 \mathrm{ml}$ phosphate buffer, $\mathrm{pH}$ 5.6). The absorbance change was measured at $265 \mathrm{~nm}$ for every $30 \mathrm{~s}$ for a period of $5 \mathrm{~min}$. One enzyme unit is equivalent to an absorbance change of 3.58 per minutes.

\section{Non-enzymatic antioxidants glutathione estimation}

The level of glutathione in the treatments with and without EDTA containing chromium was determined according to Tukendorf and Rauser (1990), using Ellman's reagent. About $500 \mathrm{mg}$ of the plant material was homogenized with mortar and pestle in $5 \mathrm{ml}$ of cold extraction buffer containing, $0.1 \mathrm{M}$ Tris- $\mathrm{HCl}(\mathrm{pH} 8.0), 10 \mathrm{mM} \mathrm{MgCl}_{2}$, $3 \mathrm{mM}$ Sodium-EDTA. The homogenate was centrifuged for $30 \mathrm{~min}$ at $15000 \mathrm{~g}$ at $4{ }^{\circ} \mathrm{C}$. The reaction mixture contained $1 \mathrm{ml}$ of the supernatant, $2 \mathrm{ml}$ of $0.4 \mathrm{M}$ Tris- $\mathrm{HCl}$ buffer

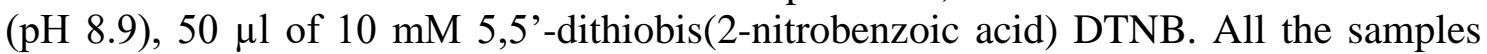
were incubated for $1 \mathrm{~h}$ at $37^{\circ} \mathrm{C}$. The absorbance was measured at $412 \mathrm{~nm}$ after $2 \mathrm{~min}$ in a spectrophotometer $\left(\sum 412=13.6 \mathrm{mM}^{-1} \mathrm{~cm}^{-1}\right)$.

\section{Statistical analysis}

The data observed in the experiment were statistically analyzed for the mean, standard deviation (SD), standard error (S.E.) and least significant difference (LSD) to determine the critical level of significance $(\mathrm{P} \leq 0.05)$ of the differences between means of treatments. 


\section{Results and discussion}

\section{Effects of Cr, EDTA and SNP on superoxide dismutase activity}

The results of SOD activity are presented in Figure $2 a$ showing the effect of different concentration of chromium with and without EDTA on superoxide dismutase activity (Units $\mathrm{mg}^{-1}$ protein) in Sesbania grandiflora and in Figure $2 b$ showing the effect of chromium and EDTA in the presence of SNP on superoxide dismutase activity (Units $\mathrm{mg}^{-1}$ protein) in Sesbania grandiflora respectively. The results after 30 days time period from Figure $2 a$ showed an increase in the SOD activity with increase in the concentration of $\mathrm{Cr}$. When compared with control plants the $\mathrm{C} 5$ treatment plants showed $80.7 \%$ increase with respect to the SOD activity. Further in the presence of chelator EDTA, the SOD activity was observed to be increased in all the treatments with EDTA when compared with control. Significant difference was noted for the treatment with highest concentration of $\mathrm{Cr}$ at both the levels $\mathrm{P} \leq 0.05$ and $\mathrm{P} \leq 0.01$. During 60 days of growth significant difference at both $\mathrm{P} \leq 0.05$ and $\mathrm{P} \leq 0.01$ were observed for the treatments $\mathrm{C} 4, \mathrm{C} 5$ and C5+EDTA, whereas treatments C3+EDTA and $\mathrm{C} 4+\mathrm{EDTA}$ showed significant difference only at one level $\mathrm{P} \leq 0.05$. The highest SOD activity was represented by the treatment C5+EDTA at 60 days of growth with 116.01 units/mg protein. Whereas in absence of EDTA the C5 plants showed $22.48 \%$ decrease in the SOD activity, this justifies the role of EDTA in enhanced metal uptake and increased oxidative stress, thereby increasing the SOD antioxidant enzymes. At 90 days there was a significant difference for C3+EDTA, C4+EDTA and C5+EDTA at both $\mathrm{P} \leq 0.05$ and $\mathrm{P} \leq 0.01$, whereas in the absence of EDTA, C3 and C4 showed difference only at $\mathrm{P} \leq 0.05$, whereas $\mathrm{C} 5$ showed significant difference at both the significant levels. Hence the significant difference between the treatments $\mathrm{Cr}$ without and with EDTA shows that, in the presence of EDTA the concentration of $\mathrm{Cr}$ is higher and it also increased with the time period. The elevation of SOD activity in general is a clear indication to detoxify the $\mathrm{O}^{-2}$ and other ROS in downstream pathways under metal stress. But in the presence of EDTA, the levels of SOD are still higher.

SOD activity increased with $150 \mu \mathrm{g} / \mathrm{g} \mathrm{Cr}$ in the presence of EDTA in Cucumis utilissimus (Sinam et al., 2011). The increase in SOD activity after $12 \mathrm{hr}$ of application of $50 \mu \mathrm{mol} / \mathrm{L}$ of $\mathrm{Cr}(\mathrm{VI})$ was also reported in Vigna radiata cv. $\mathrm{CO}_{4}$ (Shankar et al., 2005). In maize the SOD activity increases with $300 \mu \mathrm{M}$ of $\mathrm{Cr}$ in Sartaj variety (Maiti et al., 2012).

The result represented in Figure $2 b$ depicts the effects of exogenous nitric oxide in the presence of chromium and EDTA. From the figure it was clear that, when the concentration of chromium is increased from $60 \mathrm{mg} / \mathrm{Kg} \mathrm{Cr}$ to $100 \mathrm{mg} / \mathrm{Kg} \mathrm{Cr}$, the SOD activity also increases corresponding to the heavy metal increase enhanced by EDTA, which is vivid from the treatments $\mathrm{C} 1-\mathrm{C} 4$. This phenomenon of increase in SOD activity corresponding to the metal increase has been reported by different authors. Due to oxidative stress created by the metal the plant has adapted a defensive mechanism by increased production of anti-oxidative enzymes, among the known antioxidative enzymes, SOD is considered to be the first line of defense for plants anti oxidative defense system. In the presence of SNP, this condition is reversed in the present study. From this it is concluded that, C3 and C4 plants when compared with that of C7 and C8 plants, the presence of SNP in latter in spite of metal and EDTA concentration it decreased the SOD activity in those plants (i.e. C7 and C8) by $34.4 \%$ and $32.90 \%$ respectively at the end of 30 days growth period. Significant difference was depicted in 
activity of SOD in C3 and C7 for varying time periods. This shows that in the presence of SNP the SOD activity have been reduced. Based on the literature (Ferreira et al., 2010) the decreased SOD activity during treatment with SNP clearly states that nitric oxide (NO) action has created lower substrate availability and created a reversed effect. This fact was detected in the present study with the plants supplied with $250 \mu \mathrm{M}$ of SNP.

Similar results were reported in ryegrass and in Arabidopsis under $\mathrm{Cu}$ stress (Dong et al., 2014; Cobbett, 2000). Reports in sunflower and rice leaves under Cd stress by Laspina et al. (2005) and Hung and Kao (2003) have detected that in the presence of SNP, the SOD levels decreases and this low SOD activity was due to decrease in lipoperoxide levels. It increased the photosynthetic ability of the plant and confers the plant protection against oxidative stress. Similar to the above results (Caro and Puntarulo, 1998) observed the lowered levels of substrates for SOD due to NO presence in soybean embryo. Reports also suggested that nitric oxide play role even as an antioxidant thereby directly quenching the super oxide anion and regulates the oxidative damage as seen in Triticum aestivum roots grown under $\mathrm{Pb}$ induced toxicity (Kaur et al., 2015). Thus based on the above reports by various authors it could be correlated in the present work, that NO gradually scavenged the superoxide radical when SNP is supplied exogenously in the treatments $\mathrm{C} 5$ and C6. Even in the presence of combined effect of $\mathrm{Cr}$ and EDTA in the treatments $\mathrm{C} 7$ and $\mathrm{C} 8$, presence of SNP had a positive role in attenuating the oxidative stress generated by the metal and chelator.
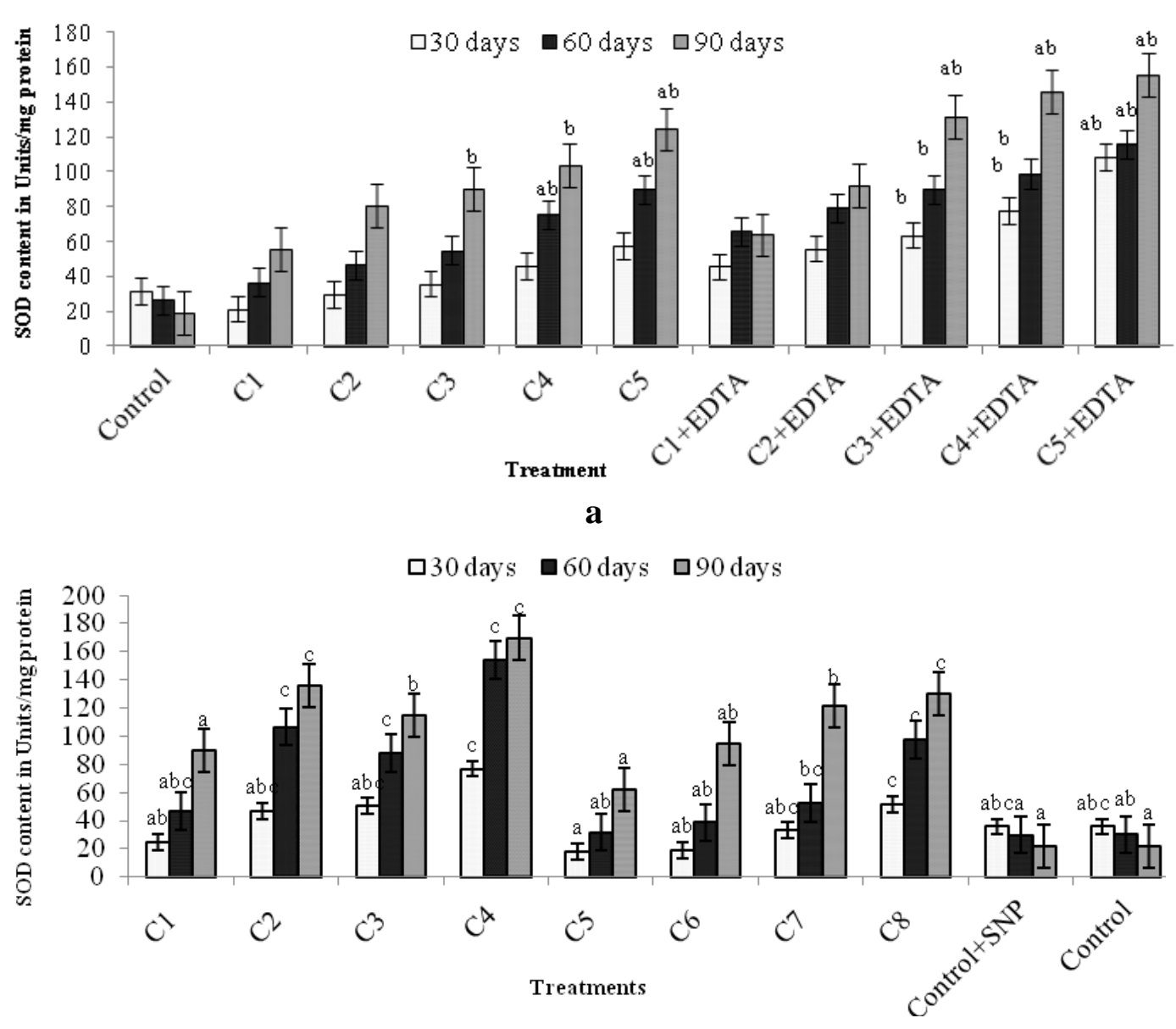

b 


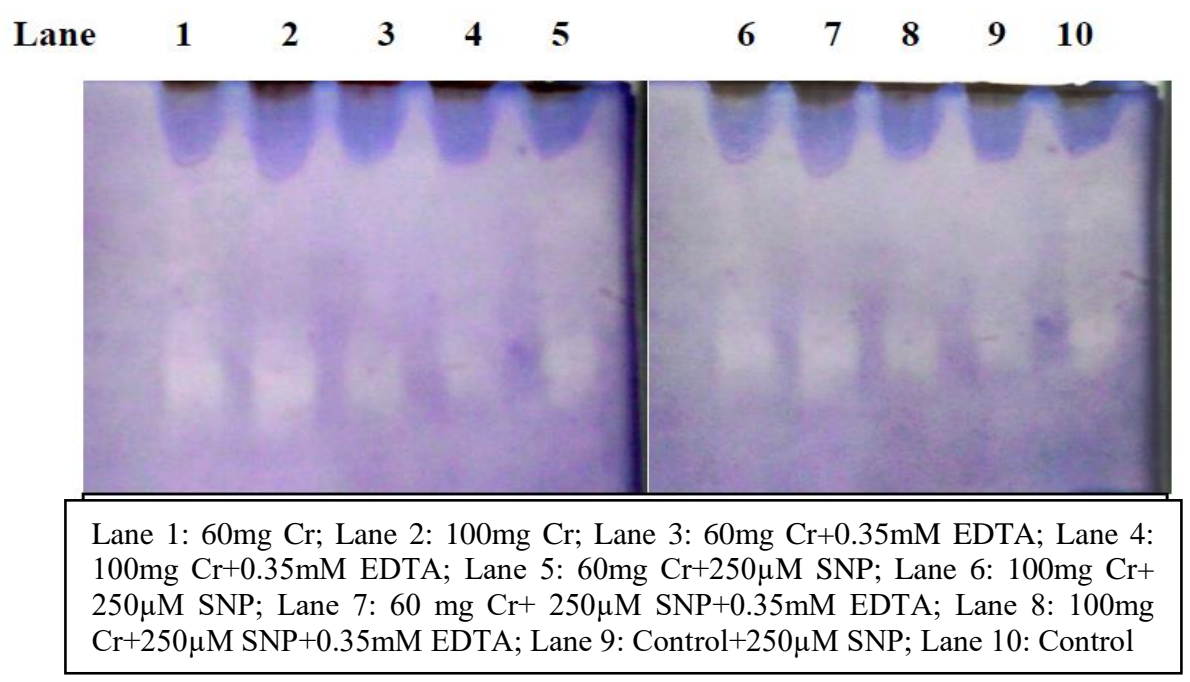

c

Figure 2. a Effect of different concentration of chromium with and without EDTA on Superoxide dismutase activity (units $\mathrm{mg}^{-1}$ protein) in Sesbania grandiflora. (Significance at $P \leq 0.05=b$, significance at $P \leq 0.01$ and $P \leq 0.05=a b$.) $\boldsymbol{b}$ Effect of chromium and EDTA in the presence of SNP on superoxide dismutase activity (units $\mathrm{mg}^{-1}$ protein) in Sesbania grandiflora. (Lower case letters that are different denote the treatments which are significantly different. Same letter indicates the treatments which are not significantly different.) $c$ Superoxide dismutase (SOD) isoenzymes activities in native gels in leaves of Sesbania grandiflora under various combinations of chromium, EDTA and SNP

SOD enzyme was distinguished by native Polyacrylamide gel electrophoresis (PAGE) experiment to determine the isoenzymes of SOD in the presence of SNPtreatment. The finding in Figure $2 c$ shows the superoxide dismutase (SOD) isoenzymes activities in native gels in leaves of Sesbania grandiflora under various combinations of chromium, EDTA and SNP, this shows the presence of one manganese superoxide dismutase (Mn-SOD) in both the control and chromium treated plants. When plants were exposed to higher concentration of chromium with $100 \mathrm{mg} \mathrm{Cr} \mathrm{Kg}^{-1}$, it was observed that MnSOD was apparently affected in SNP treated plants which is clear from the bands which were clearly less intense (lane 8) than the other treatments (lane 4) in the absence of SNP.

\section{Effects of Cr, EDTA and SNP on catalase activity}

Catalase, a tetrameric heme-containing enzyme, that degrade $\mathrm{H}_{2} \mathrm{O}_{2}$ rapidly and more sensitive to excess $\mathrm{Cr}$, where it readily binds to thiol groups and inactivates the thiolcontaining enzyme (Luna et al., 1994). Similar to SOD activity, the catalase activity in the study represented in Figure $3 a$ shows the effect of different concentration of chromium with and without EDTA on catalase activity (Units $\mathrm{mg}^{-1}$ protein) in Sesbania grandiflora. The activity was found to be increased with higher concentrations of $\mathrm{Cr}$ in the presence of EDTA. When compared with the control, the highest catalase activity was noted for higher concentration of $\mathrm{Cr}$ in presence of EDTA (C5+EDTA) which was observed to be $55.5 \%$ increased than non-EDTA plants (C5) at 60 days growth period. The CAT activity also increased with the time period from 60 days compared to 90 days due to the persistent effect of chromium action. Hence under this metal stress reactive 
oxygen species (ROS) production is elevated leading to oxidative damage. Statistically it was noted that at 60 days significant change was exhibited at $\mathrm{P} \leq 0.05$ and $\mathrm{P} \leq 0.01$ for the treatments $\mathrm{C} 1, \mathrm{C} 1+$ EDTA and C2+EDTA. Similarly at 90 days C4 and C2+EDTA showed significant difference $(\mathrm{P} \leq 0.05$ and $\mathrm{P} \leq 0.01)$. Statistically also EDTA proves its higher metal enhancement activity, since from Figure 3 it is clear that, at 60 and 90 days of the growth the treatment C2+EDTA alone showed significant difference at the $\mathrm{p}$ values $\mathrm{P} \leq 0.05$ and $\mathrm{P} \leq 0.01$, stating that the presence of EDTA with higher concentration of $\mathrm{Cr}$ had influence on the increased activity. The combined action of SOD and CAT is critical in mitigating the effects of oxidative stress, since SOD show customary action on the superoxide anion converting it to $\mathrm{H}_{2} \mathrm{O}_{2}$ which is another reactive intermediate and later $\mathrm{H}_{2} \mathrm{O}_{2}$ gets converted it to water and oxygen (Mates, 2000). Catalase enzyme increases with increasing concentration of $\mathrm{Cr}$ in Ocimum tenuiflorum and Sesbania sesban (Rai et al., 2004; Bakiyaraj et al., 2014).

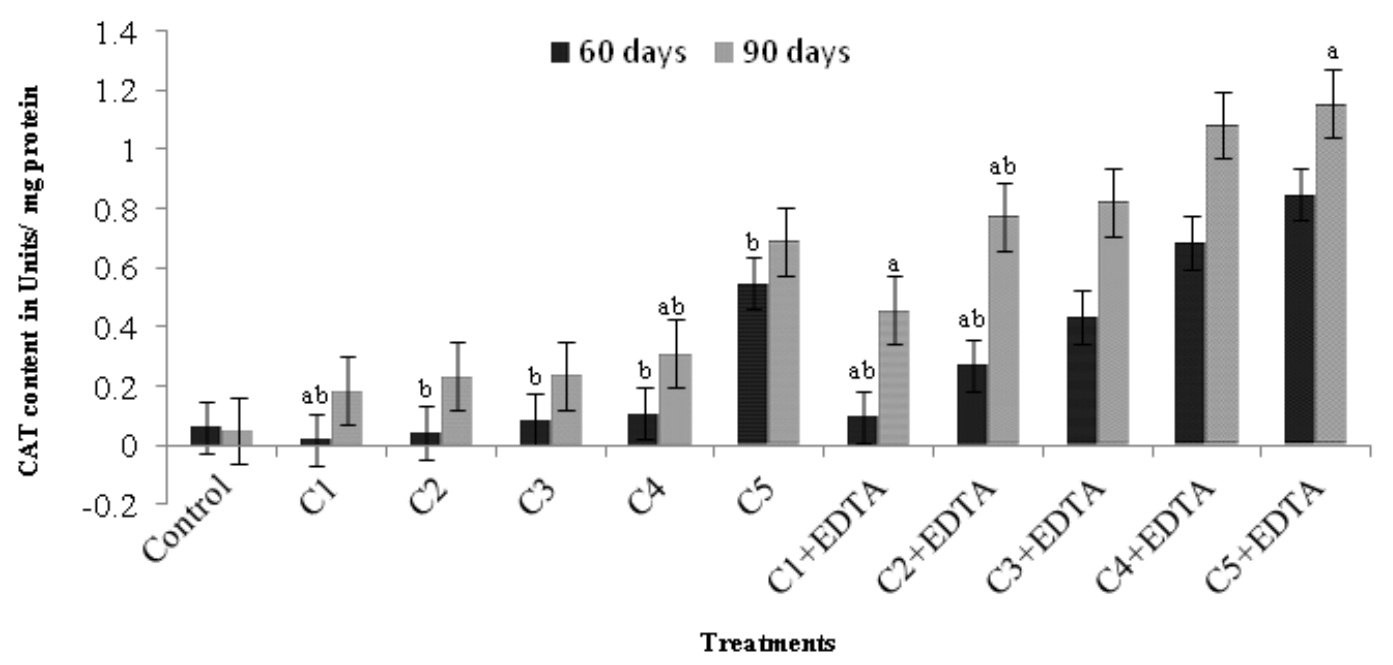

$\mathbf{a}$

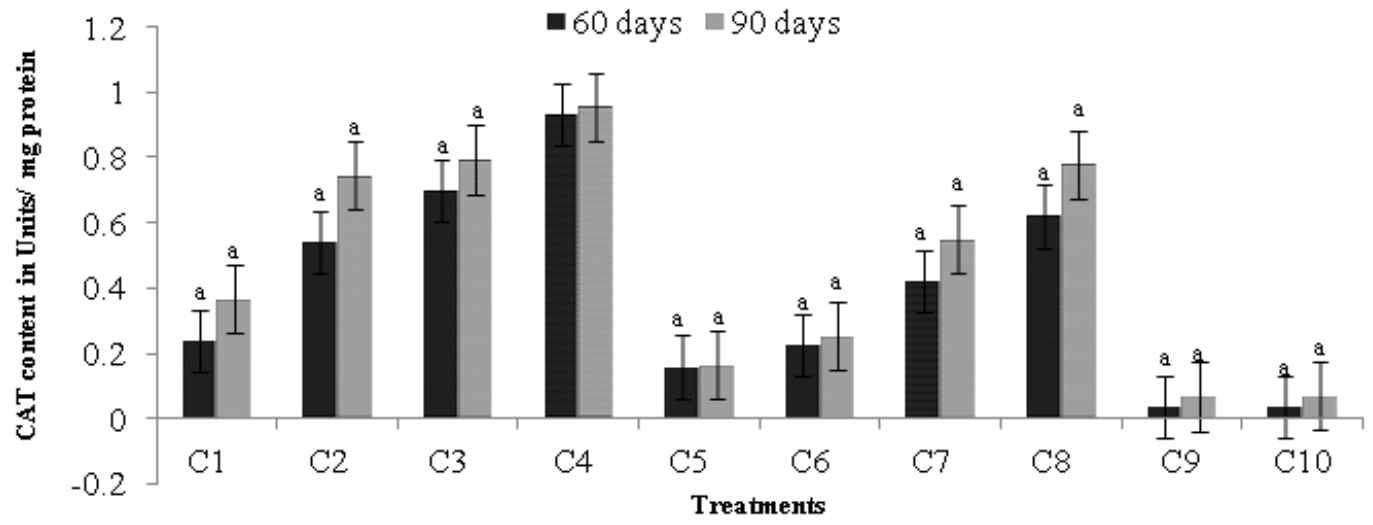

b

Figure 3. a Effect of different concentration of chromium with and without EDTA on catalase activity (units $\mathrm{mg}^{-1}$ protein) in Sesbania grandiflora. (Significance at $P \leq 0.05=b$, significance at $P \leq 0.01$ and $P \leq 0.05=a b$.) $\boldsymbol{b}$ Effect of chromium and EDTA in the presence of SNP on catalase activity (units $\mathrm{mg}^{-1}$ protein) in Sesbania grandiflora. (Lower case letters that are different denote the treatments which are significantly different. Same letters indicate the treatments which are not significantly different) 
The results of catalase activity in the presence of chromium and EDTA, and exogenous application of SNP are represented in Figure $3 b$ showing the effect of chromium and EDTA in the presence of SNP on catalase activity expressed in (Units $\mathrm{mg}^{-1}$ protein) in Sesbania grandiflora. From the figure it is clear that, the catalase activity increased with increase in chromium and EDTA levels, which is apparent from the treatments $\mathrm{C} 2$ and $\mathrm{C} 4$. But the treatments C5-C8 with SNP the activity of catalase decreased, with corresponding increase in the concentration of chromium.

According to Ferreira et al. (2010), the cause of the decrease in CAT activity was due to reduced substrates for CAT activity as observed in SNP-pretreated soybean plants. This fact was paralleled with the present study that the decreased $\mathrm{H}_{2} \mathrm{O}_{2}$ production as a consequence of the NO effect, approve protection against ROS in SNP administered C7 and C8 plants. Our study is in concordance with the above statement that, in the presence of SNP the catalase activity is reduced in C5 and C6. This is also applicable to the treatments $\mathrm{C} 7$ and $\mathrm{C} 8$, where in spite of chromium and EDTA the catalase activity was reduced in these plants. Thus when a comparison was made between $\mathrm{C} 3$ and $\mathrm{C} 4$ plants with their counter parts $\mathrm{C} 7$ and $\mathrm{C} 8$ plants, presence of SNP in latter, reduced the CAT activity by $31.6 \%$ in case of $60 \mathrm{mg} \mathrm{Cr}$, SNP and EDTA and $18.94 \%$ in case of $100 \mathrm{mg} \mathrm{Cr}$, SNP and EDTA at 90 days growth period. Hence compared with the control the antioxidant activity was decreased in SNP treated plants which clearly explains the potential of NO, which confers resistance to heavy metal stress created oxidative damage in Sesbania grandiflora. And moreover the reduction of catalase activity and its decreased levels to normalcy was experienced after addition of SNP indicating the cell response to NO action and thus decreasing the ROS generation inside the cell. Similar results were reported by Dalurzo et al. (1996) in Pea leaves and (Cobbett, 2000) in Arabidopsis showing the decline in CAT activity.

\section{Effects of Cr, EDTA and SNP on ascorbate peroxidase (APX) activity}

The APX activity for Exp.1 is presented in Figure $4 a$ showing the effect of different concentration of chromium with and without EDTA on ascorbate peroxidase activity (Units $\mathrm{mg}^{-1}$ protein) in Sesbania grandiflora. From the figure, it is clear that the APX activity increased in the treatments of chromium in the presence of EDTA than experienced by the treatment in the absence of EDTA. The levels of APX increased in 30 days of plant growth, and when compared with the control, the value of 4.6 units/mg protein observed in C5+EDTA plants, is $10.96 \%$ higher than C5 plants with 0.51 units/mg protein of APX. A significant difference in the treatments was observed for the higher concentration at both the levels $\mathrm{P} \leq 0.05$ and $\mathrm{P} \leq 0.01$ in the presence of EDTA (C4+EDTA and C5+EDTA). After 30 days, the APX activity increased with increase in the chromium concentration. This increase in the enzyme activity could be correlated with action of ascorbate peroxidase that was more efficient in destroying $\mathrm{H}_{2} \mathrm{O}_{2}$ under $\mathrm{Cr}$ stress in the presence of chelator. Statistically at 60 days, there was a significant difference noted for all the treatments at both $\mathrm{P} \leq 0.05$ and $\mathrm{P} \leq 0.01$, except for C2+EDTA and C5+EDTA which showed significant difference only at one level $\mathrm{P} \leq 0.05$. Among the EDTA treated plants $\mathrm{C} 1+\mathrm{EDTA}$ was the only treatment that showed significant difference at $\mathrm{P} \leq 0.05$, whereas all the treatments in the absence of EDTA significantly differed $(\mathrm{P} \leq 0.05$ and $\mathrm{P} \leq 0.01)$. When compared with the control, the progressive level of APX showed an increase in the activity of APX in the treatment C5+EDTA at 90 days with 8.6 units/mg protein of the enzyme. The study is in agreement with the reports of (Karuppanapandian et al., 2006a) that, the antioxidant 
enzyme increase was due the antioxidative capacity stimulated by $\mathrm{Cr}$, which caused the conversion of $\mathrm{H}_{2} \mathrm{O}_{2}$ to $\mathrm{H}_{2} \mathrm{O}$ and $\mathrm{O}_{2}$. The high levels of APX produced, due to the higher concentrations of $\mathrm{Cr}$ in the presence of EDTA, uses ascorbic acid as a reductant in the first step of the ascorbate-glutathione cycle (Mittova et al., 2003 and Smirnoff, 2000). Similar results were reported by Rai et al. (2006) in sugarcane plants exposed to hexavalent chromium. $\mathrm{Cr}$ and $\mathrm{Al}$ induced $\mathrm{H}_{2} \mathrm{O}_{2}$ accumulations in wheat and green gram seedlings were also found to significantly elevate the APX activity (Sharma and Sharma, 1996). APX plays an important role in scavenging $\mathrm{H}_{2} \mathrm{O}_{2}$ which is a systemic signal for the induction of APX (Morita et al., 1999).

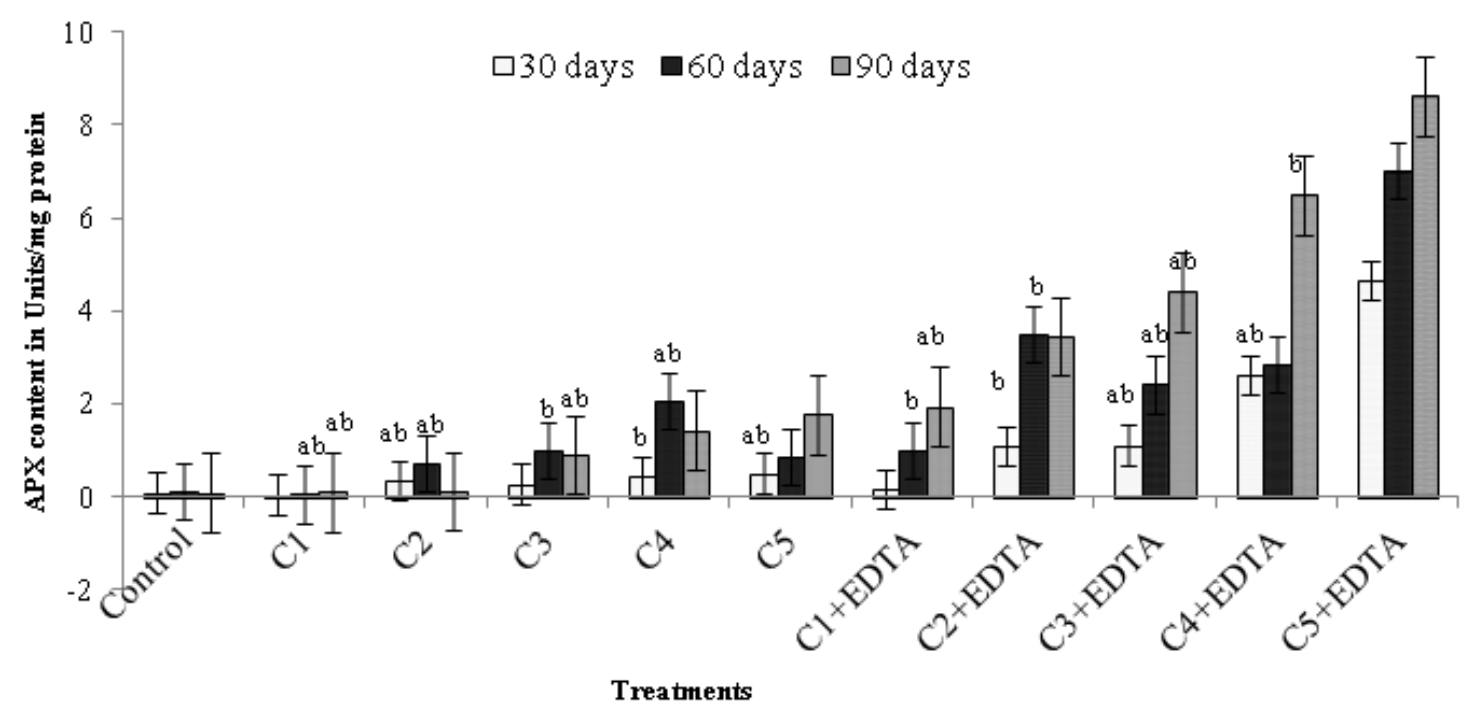

a

$\square 30$ days $\square 60$ days $\square 90$ days

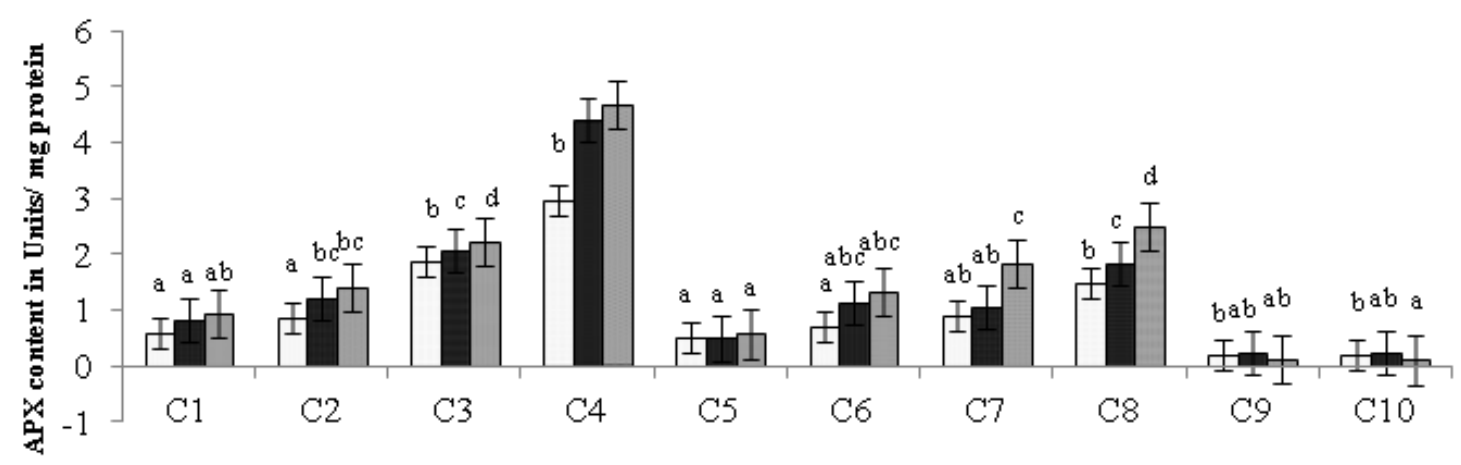

Treatments

b

Figure 4. a Effect of different concentration of chromium with and without EDTA on ascorbate peroxidase activity (units $\mathrm{mg}^{-1}$ protein) in Sesbania grandiflora. (Significance at $P \leq 0.05=b$, significance at $P \leq 0.01$ and $P \leq 0.05=a b$.) $\boldsymbol{b}$ Effect of chromium and EDTA in the presence of SNP on ascorbate peroxidase activity (units $\mathrm{mg}^{-1}$ protein) in Sesbania grandiflora. (Lower case letters that are different denote the treatments which are significantly different. Same letters indicate the treatments which are not significantly different) 
The effects of APX activity in the presence of chromium and EDTA, with exogenous application of $250 \mu \mathrm{M} \mathrm{SNP}$ are represented in Figure $4 b$ showing the effect of chromium and EDTA in the presence of SNP on ascorbate peroxidase activity (Units $\mathrm{mg}^{-1}$ protein) in Sesbania grandiflora. From Exp.1, it was concluded that, the APX activity was found increased at higher chromium levels with EDTA, due to higher metal accumulation which was assisted in presence of EDTA. From Exp.1 also it is evident that, in order to overcome the oxidative stress, the APX activity increased in EDTA treated plants as a plant adaptive defence mechanism, which is evident from the treatments $\mathrm{C} 3$ and $\mathrm{C} 4$ (60 and $100 \mathrm{mg} \mathrm{Cr} \mathrm{kg}^{-1}$ with $0.35 \mathrm{mM}$ EDTA). The increased APX activity was observed for higher concentrations of chromium with increase in time period (C5, C5+EDTA), whereas C2, C4 and C2+EDTA plants exhibited lesser variation in APX activity during 90 days. Similarly the plants supplied with $250 \mu \mathrm{M}$ SNP, showed decreased APX activity. This is obvious when comparison is made between $\mathrm{C} 3$ and $\mathrm{C} 4$ and $\mathrm{C} 7$ and $\mathrm{C} 8$ plants, that presence of SNP has decreased the APX activity by $17.56 \%$ (between C3 and C7) and 47\% (between C4 and C8). Significant difference was depicted in $\mathrm{C} 8$ during 60 and 90 days compared to $\mathrm{C} 4$. This decrease in APX activity from the present study could be correlated with Hiner et al. (2000) and Talukdar (2012b) that, low availability of reduced ascorbate, its co-factor, or inhibition of its isoforms by excess $\mathrm{H}_{2} \mathrm{O}_{2}$ or both, caused reduced APX activity in Lathyrus sativus by the latter. Hence in the present study the lower ascorbate levels created by the nitric oxide have reduced the stress levels and hence a reduced APX activity was observed. Similar results were reported in wheat roots (Singh et al., 2008).

\section{Effects of Cr, EDTA and SNP on glutathione reductase (GR) activity}

The results for GR activity after 30,60 and 90 days are presented in Figure $5 a$ showing the effect of different concentration of chromium with and without EDTA on glutathione reductase activity (Units $\mathrm{mg}^{-1}$ protein) in Sesbania grandiflora. The figure denoted an increasing GR activity corresponding to the increasing concentration of the chromium and increased further in the presence of EDTA. The treatment C5 was recorded with 0.38 units/mg protein of GR content which corresponds to a decreased percentage of $58.24 \%$, when compared with that of C5+EDTA plants with 0.91 units/mg protein. Statistically there was significant difference for the treatments C5, C3+EDTA and C5+EDTA after 30 days at $\mathrm{P} \leq 0.05$ and $\mathrm{P} \leq 0.01$. During 60 days of growth $\mathrm{C} 4, \mathrm{C} 5$ and $\mathrm{C} 3+\mathrm{EDTA}$ showed significant difference. At 90 days there was statistical difference for $\mathrm{P} \leq 0.05$ and $\mathrm{P} \leq 0.01$ in all the treatments with and without EDTA, except for $\mathrm{C} 1$. Thus the determination of GR content from Exp.1 concludes that, the GR levels increased with the concentration of the treatments and it is duration dependent. Similar results were also reported in Indian mustard (Diwan et al., 2009) stating that the activity of GR under $\mathrm{Cr}$ treatment was concentration as well as duration dependent.

GR is a flavoenzyme, oxidoreductase, which catalyze the conversion of oxidized glutathione to reduced glutathione, which is found in both prokaryotes and eukaryotes. It is a prospective enzyme for the (Ascorbate glutathione) ASH-GSH cycle and plays a vital role in defense system against ROS by sustaining the reduced status of (Glutathione) GSH (Romero-Puertas et al., 2006; Gill and Tuteja, 2010).

GR content increased under Cr stress in Vigna radiata roots (Shankar et al., 2004). In another study (Nehnevajova et al., 2012), the activity of GR was strongly increased in young seedlings exposed to heavy metals and the enzyme activities were particularly 
pronounced in mutant lines of sunflower. Increased GR activity was noted (Thounaojan et al., 2012) in $\mathrm{Cu}$ treated Oryza sativa over control and, the roots showed greater activity than shoot. According to Yadav et al. (2010) chromium stress induced the production of the GR and Cr detoxification in Jatropha curcus plant.
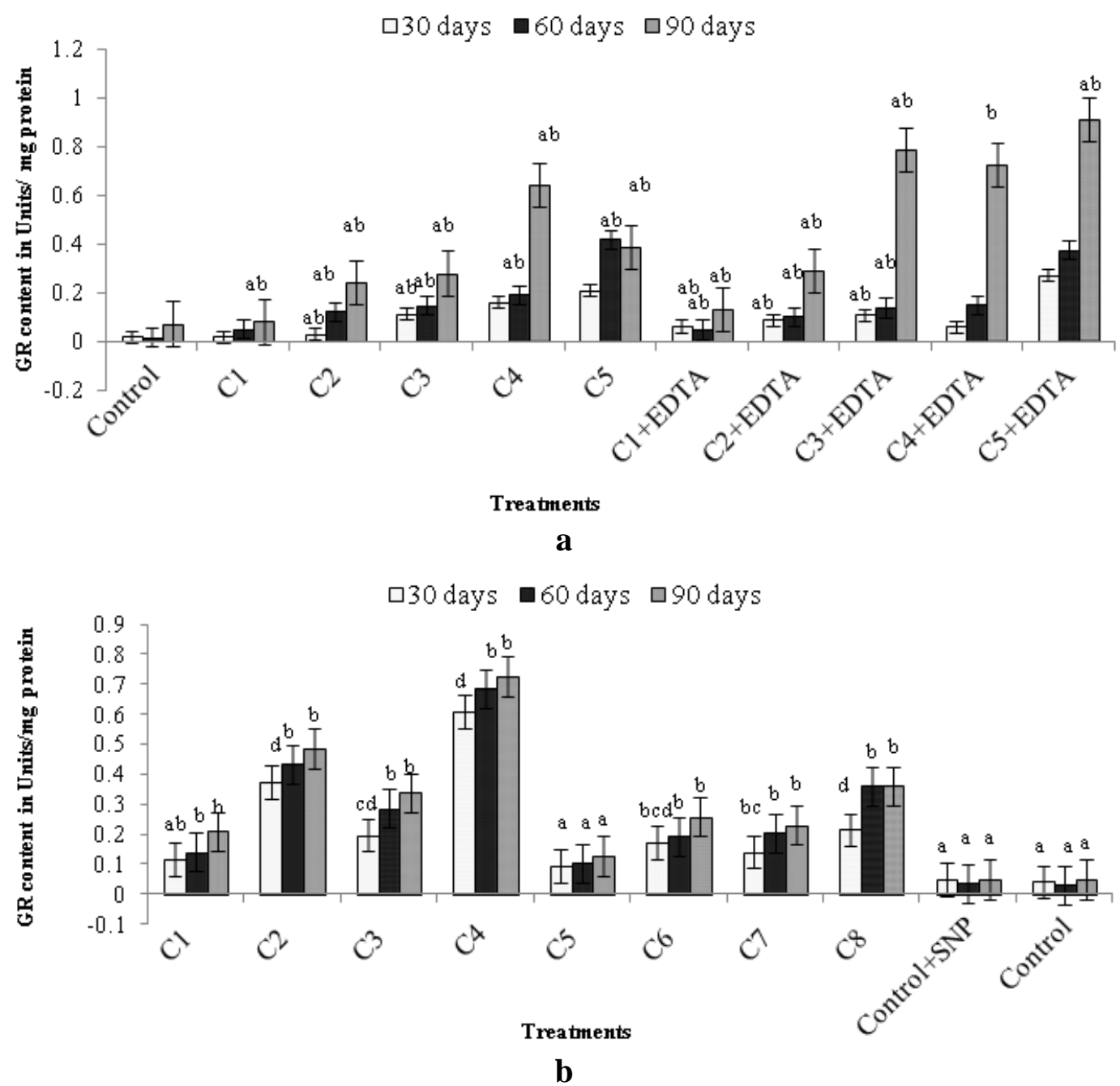

Figure 5. a Effect of different concentration of chromium with and without EDTA on glutathione reductase activity (units $\mathrm{mg}^{-1}$ protein) in Sesbania grandiflora. (Significance at $P \leq 0.05=b$, significance at $P \leq 0.01$ and $P \leq 0.05=a b$.) $\boldsymbol{b}$ Effect of chromium and EDTA in the presence of SNP on glutathione reductase activity (units $\mathrm{mg}^{-1}$ protein) in Sesbania grandiflora. (Lower case letters that are different denote the treatments which are significantly different. Same letters indicate the treatments which are not significantly different)

According to Diwan et al. (2012) APX and GR maintain the $\mathrm{H}_{2} \mathrm{O}_{2}$ level. The increased level of $\mathrm{H}_{2} \mathrm{O}_{2}$ when exported to cytosol, create an adverse effect due to formation of hydroxyl radicals through the metal-catalyzed Haber-Weiss reaction. In the present study the increased activities of APX and GR in higher concentrations in $\mathrm{Cr}$ treated plants in the presence of EDTA shows that they were functioning concurrently to remove $\mathrm{H}_{2} \mathrm{O}_{2}$. 
Glutathione reductase catalyzes the reduction of GSH, a molecule involved in many metabolic regulatory and anti oxidative processes in plants. GR catalyses the NADPH dependent reaction of disulphide bond of GSSG (oxidized glutathione). It is thus important for maintaining the GSH (reduced glutathione) pool (Reddy and Raghavendra, 2006). GR and GSH play crucial role in determining the tolerance of a plant under various stress (Chalapathi Rao and Reddy, 2008).

The GR activity with SNP treated plants are represented in Figure $5 b$ showing the effect of chromium and EDTA in the presence of SNP on glutathione reductase activity (Units $\mathrm{mg}^{-1}$ protein) in Sesbania grandiflora. It depicts that there is an elevation of the scavenging enzyme in the treatments $\mathrm{C} 3$ and $\mathrm{C} 4$ in order to counter act $\mathrm{Cr}$-induced stress in the presence of chelator compared to its absence in $\mathrm{C} 1$ and $\mathrm{C} 2$. According to Shigeoka et al. (2002) APX and GR are the two main enzymes of the ascorbateglutathione cycle, which are localized mainly in chloroplasts and play an important role in combating oxidative stress. This is proved in the present study that in plants treated with $\mathrm{Cr}$ and EDTA, there is a considerable increase in the GR content.

Further comparing with other treatments, it is slightly reversed upon addition of SNP. The treatment plants C5 and C6 supplied with $250 \mu \mathrm{M}$ of SNP in the presence of 60 and $100 \mathrm{mg} \mathrm{Cr} \mathrm{kg}^{-1}$, the oxidative stress created by the metal is reduced. In treatments $\mathrm{C} 7$ and $\mathrm{C} 8$ despite the presence of EDTA and Cr, addition of SNP reduced the stress by showing reduction in the enzyme activity which reduced the stress by $33.3 \%$ (C3 and $\mathrm{C} 7$ ) and 50\% (C4 and C8) respectively. In other words, SNP as a NO donor has an ameliorating effect on Cr and EDTA induced stress. Supporting facts by Singh et al. (2008) reported similar reduction in GR activity upon SNP treatment against $\mathrm{Cd}$ toxicity in wheat roots.

\section{Effects of Cr, EDTA and SNP on ascorbic acid oxidase activity}

The activities of Ascorbic acid oxidase determined in the leaves of Sesbania grandiflora are presented in Figure $6 a$ showing the effect of different concentration of chromium with and without EDTA on ascorbic acid oxidase activity (units $\mathrm{mg}^{-1}$ protein) in Sesbania grandiflora. From the results it is clear that when the concentration of the chromium increases from 20-100 $\mathrm{mg}$, there is an increase in the activity of the antioxidant enzyme ascorbic acid oxidase. Moreover when compared with the control, the activity of the enzyme increased by $89.4 \%, 115.7 \%, 105.2 \%, 363.1 \%$ and $410.5 \%$ in the presence of EDTA in C1+EDTA to C5+EDTA plants respectively corresponding to chromium concentration noted after 60 days of growth. When compared with C5 plants, C5+EDTA showed $94 \%$ increase in ascorbic acid oxidase activity. Statistical significant difference was noted in all the treatments at $\mathrm{P} \leq 0.05$. After 30 days of growth, treatments C3+EDTA and C4+EDTA showed significant difference at both the levels $\mathrm{P} \leq 0.05$ and $\mathrm{P} \leq 0.01$. At 60 days of growth $\mathrm{C} 2, \mathrm{C} 3$, and $\mathrm{C} 4$ showed significant difference at $\mathrm{P} \leq 0.05$ and $\mathrm{P} \leq 0.01$. Similarly after 90 days, significant difference was exhibited by the treatments $\mathrm{C} 1, \mathrm{C} 2$ and $\mathrm{C} 3$. Thus the present study shows that EDTA had an influence on the ascorbic acid oxidase enzyme concentration determination in the presence of increasing concentrations of $\mathrm{Cr}$.

Ascorbate is a universal soluble antioxidant that is involved in various physiological mechanisms of plant, which exists in photosynthetic organisms. The ascorbate is considered to be the most important substrate for decomposition of hydrogen perodxide $\mathrm{H}_{2} \mathrm{O}_{2}$ detoxification (Singh et al., 2005). High AO activity is associated with the cell wall ascorbate and cell wall localized ascorbate oxidase (AO) that function to control 
growth and expanding cells and as a model that links wall ascorbate and ascorbate oxidase to cell wall extensibility (Smirnoff, 1996).
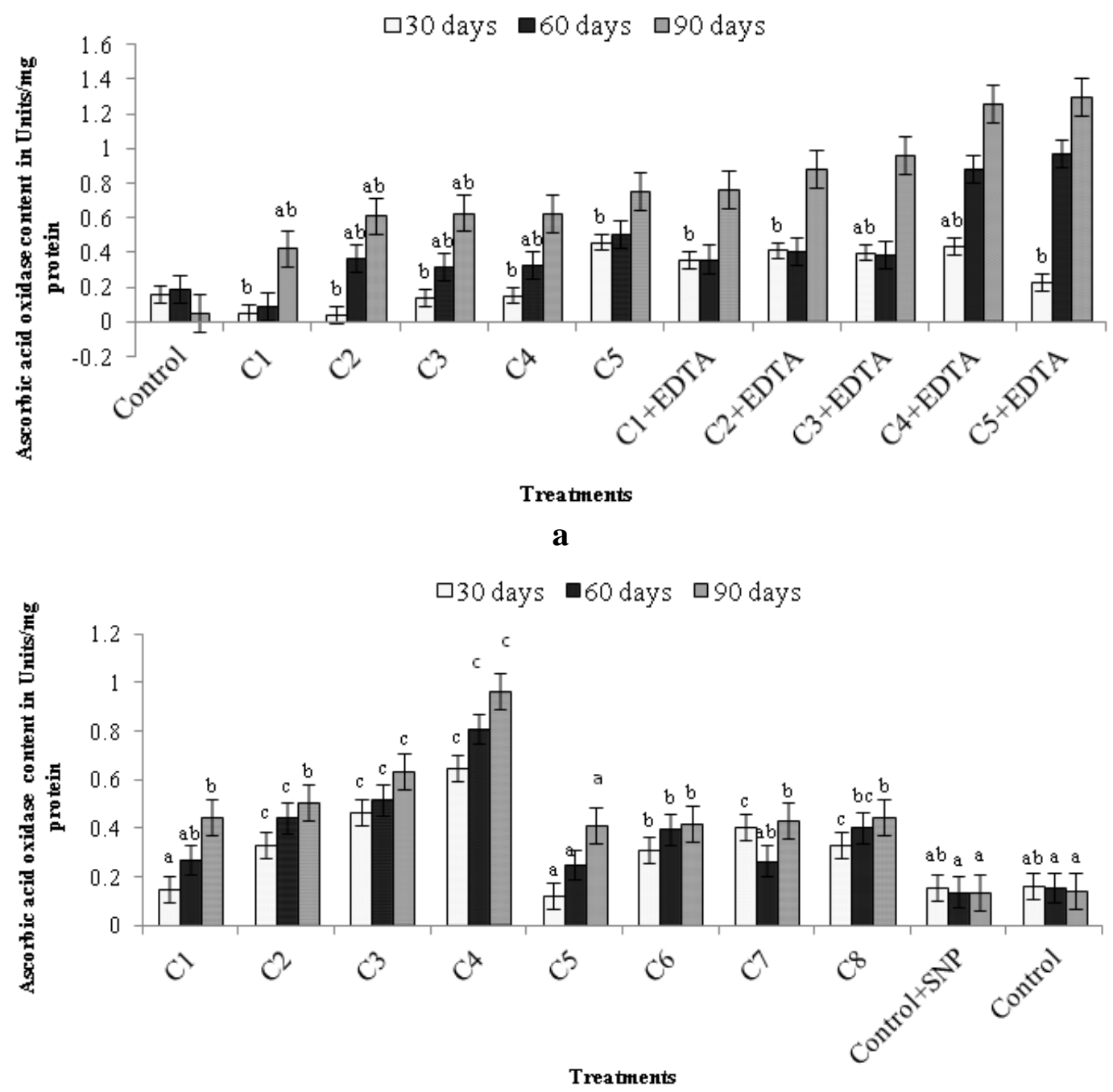

b

Figure 6. a Effect of different concentration of chromium with and without EDTA on ascorbic acid oxidase activity (units $\mathrm{mg}^{-1}$ protein) in Sesbania grandiflora. (Significance at $P \leq 0.05=b$, significance at $P \leq 0.01$ and $P \leq 0.05=a b$.) $\boldsymbol{b}$ Effect of chromium and EDTA in the presence of SNP on ascorbic acid oxidase activity (units $\mathrm{mg}^{-1}$ protein) in Sesbania grandiflora. (Lower case letters that are different denote the treatments which are significantly different. Same letters indicate the treatments which are not significantly different)

Ascorbate is considered to be the primary as well as a secondary antioxidant, which binding to the metals, affects their movement across biological membranes, or act as a reductant. Reports suggested that, the ascorbate content in Vigna aconitifolia roots increased significantly under cadmium stressed conditions (Vijendra et al., 2016). Similarly the activity of ascorbate oxidase enzyme was determined for a period of three months for the plants treated with 60 and $100 \mathrm{mg}$ of $\mathrm{Cr}$ with $0.35 \mathrm{mM}$ EDTA and 250 $\mu \mathrm{M}$ SNP. The result represented in Figure $6 b$ explains the effect of chromium and EDTA in the presence of SNP on ascorbic acid oxidase activity (Units $\mathrm{mg}^{-1}$ protein) in 
Sesbania grandiflora. The figure articulates that, the enzyme activity increased from 30 to 90 days in treatments (C1-C4) in the presence of chromium and EDTA as a defensive mechanism for the plant to withstand the oxidative stress formed due to the reactive oxygen species (ROS) liberated due to high metal concentrations. But in the treatments (C5-C8) the result showed that, the presence of nitric oxide in the plants under the treatments showed decline in the enzyme levels, where the C8 plants showed a decreased percentage of $54.1 \%$ when compared with C4 plants in the absence of SNP, stating the fact that nitric oxide can counteract $\mathrm{Cr}$ and EDTA induced oxidative stress.

Such effects were confirmed by the other antioxidant enzymes studied and such studies reported that $\mathrm{NO}$ can detoxify or scavenge ROS directly or it can also react with $\mathrm{O}_{2}{ }^{--}$and generate peroxynitrite $\left(\mathrm{ONOO}^{-}\right)$(Martinez et al., 2000; Neill et al., 2003). Thus SNP protects plants against Cr+ EDTA induced oxidative stress. The SNP effect in the present study represents the antioxidant property of $\mathrm{NO}$ for suppression of high levels of Cr-triggered ROS.

\section{Effects of Cr, EDTA and SNP on glutathione activity}

Glutathione (GSH), a tri-peptide is most abundant low molecular weight thiol in all mitochondria-bearing eukaryotes including plants. In plants, GSH is involved in defence against ROS (Foyer and Noctor, 2005; Mullineaux and Rausch, 2005), sequestration of heavy metals (Cobbett and Goldsbrough, 2002) and is one of the major source of non-protein thiols in most plant cells (Freeman et al., 2004). The glutathione content in the chromium treated plants with and without EDTA in the present study represented in Figure $7 a$ shows the effect of different concentration of chromium with and without EDTA on glutathione content $\left(\mu \mathrm{g} . \mathrm{FW}^{-1}\right)$ in Sesbania grandiflora. When compared with the control the glutathione content increased with the increase in the concentration of $\mathrm{Cr}$ in the presence of EDTA. The highest glutathione content was recorded for the treatment with $100 \mathrm{mg}$ of $\mathrm{Cr}+0.35 \mathrm{mM}$ EDTA with $280.63 \mu \mathrm{g}$.

With increase in time period from 30 to 90 days the glutathione content was found to be increased by $92.9 \%$ in C5+EDTA plant. All the treatments showed significant difference at both levels $\mathrm{P} \leq 0.05$ and $\mathrm{P} \leq 0.01$. But at 60 days of growth all the treatments showed significant difference at both levels $\mathrm{P} \leq 0.05$ and $\mathrm{P} \leq 0.01$ except $\mathrm{C} 5$ and C5+EDTA. This validates that, higher concentrations of $\mathrm{Cr}$ have influence on glutathione concentration in plant under heavy metal stress and this effect being more pronounced in the presence of EDTA. Thus at higher concentration of $\mathrm{Cr} /$ chelator the level of glutathione increased with time.

Furthermore, elevated GSH concentration is correlated with the ability of plants to withstand metal-induced oxidative stress. Enhanced antioxidant activity in the leaves and chloroplast of Phragmites australis was mainly associated with a large pool of GSH resulting in protection of many photosynthetic enzymes against the thiophilic bursting of Cd (Pietrini et al., 2003). Similarly, increased concentration of GSH has been reported in Pisum sativum, Sedum alfredii and Vigna mungo (Metwally et al., 2005; Sun et al., 2007; Molina et al., 2008).

Various non enzymatic antioxidants play an important role in plant defense mechanism under heavy metal stress. In Oryza sativa there was no observed significant change in the ascorbate (AsA) content in developing seedlings under Cr (VI) (Panda, 2007); however, the reduced glutathione (GSH) content increased by $30 \%$ and $52 \%$ at $50 \mathrm{mM}$ and $100 \mathrm{mM}$ of $\mathrm{Cr}$ (VI), respectively, after $48 \mathrm{~h}$ of exposure. Elevated expression of genes encoding these enzymes under $\mathrm{Cr}$ (VI) toxicity suggests defensive 
role of glutathione under heavy metal stress according to Zulfiqar et al. (2011), these observations show the involvement of glutathione metabolism in the alleviation of $\mathrm{Cr}$ (VI) toxicity by providing protection against oxidative stress.

\section{$\square 30$ days $\mathbf{6} 60$ days $\square 90$ days}

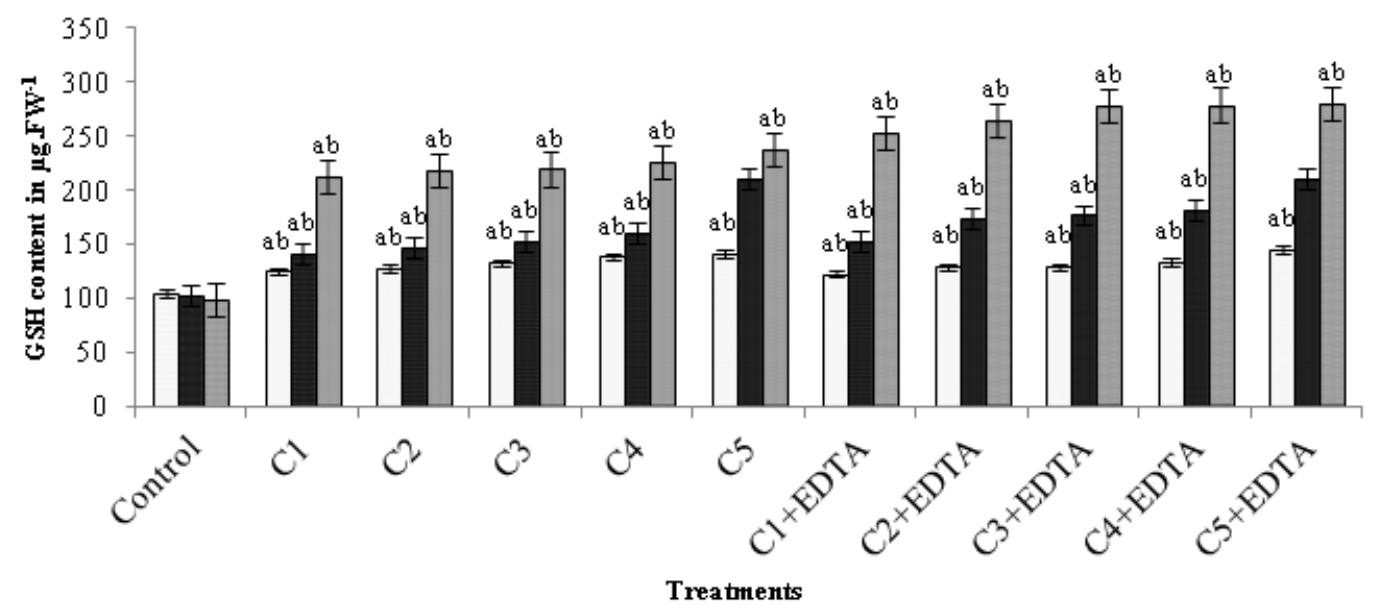

a

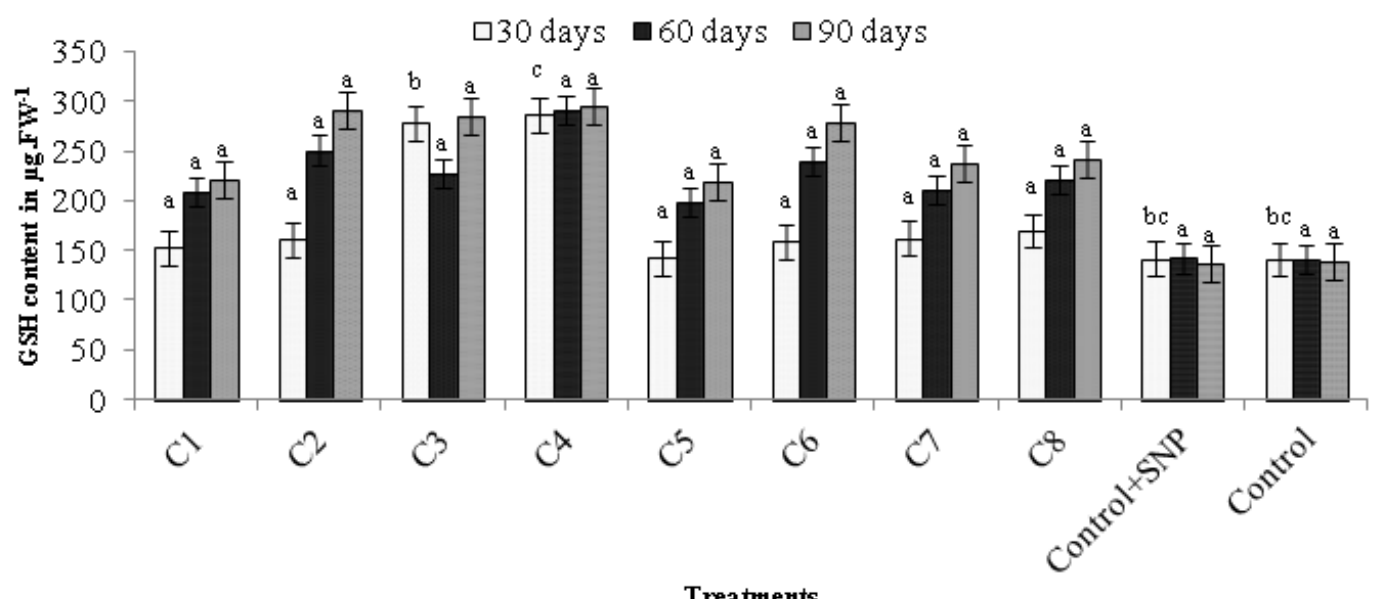

b

Figure 7. a Effect of different concentration of chromium with and without EDTA on glutathione content $\left(\mu g . F W^{-1}\right)$ in Sesbania grandiflora. (Significance at $P \leq 0.05=b$, significance at $P \leq 0.01$ and $P \leq 0.05=a b$.) $\boldsymbol{b}$ Effect of chromium and EDTA in the presence of SNP on glutathione content ( $\mu$ g. $F W^{-1}$ ) in Sesbania grandiflora. (Lower case letters that are different denote the treatments which are significantly different. Same letters indicate the treatments which are not significantly different)

A marked increase in GSH levels in Zea mays, Brassica spp. and L. esculentum upon exposure to 5-10 $\mathrm{mg}^{-1} \mathrm{Cr}$ (VI) (Sanita di Toppi et al., 2002). A positive correlation between GSH and Cr levels has also been observed in Salvia natans (Dhir et al., 2009) and Brassica juncea (Diwan et al., 2010).

GSH is one of the crucial metabolites in plants which are considered as most important intracellular defense against ROS induced oxidative damage. GSH is necessary to maintain the normal reduced state of cells so as to counteract the inhibitory 
effects of ROS induced oxidative stress. It is a potential scavenger of ${ }^{1} \mathrm{O}_{2}, \mathrm{H}_{2} \mathrm{O}_{2}$ and most dangerous ROS like $\mathrm{OH}^{-}$.

The observations made on the glutathione content with SNP treated plants represented in Figure $7 b$ show the effect of chromium and EDTA in the presence of SNP on glutathione content $\left(\mu \mathrm{g}\right.$. $\left.\mathrm{FW}^{-1}\right)$ in Sesbania grandiflora depicts that increased glutathione content with chromium and EDTA treated plants (C1-C4) was reduced in the presence of SNP. From the figure, it shows that treatments, C5 to C8 exhibited reduced glutathione content when compared with control and other treatment plants.

A comparison between the treatments in presence and absence of SNP showed that, presence of SNP in C7 and C8 plants showed a decreased percentage of glutathione content with $16.5 \%$ and $17.9 \%$, with that of their respective counterparts C3 and C4 plant.

The reports indicate that the heat-treated Triticum aestivum plants showed a reduced GSSG content compared to heat treated plants, due to the SNP supplement (Hasanuzzaman et al., 2012). Literatures also suggest that during stress conditions the glutathione levels inside the cell increases as a consequence to confer resistant against oxidative stress created by heavy metal (Hasanuzzaman et al., 2017). This was paralleled with the present study that the GSH content was found to increase with higher concentrations of chromium in the presence of EDTA. But Exp.2 concluded that, though there was increase in GSH content in chromium and EDTA treated plants, the SNP supplemented plants showed a decreased GSH content than the normal.

This could be justified that the oxidative stress generated by metal and chelator was mitigated by the action of SNP, there by manifesting the key role of nitric oxide in acting as a direct scavenger of ROS and thus reduced the oxidative stress in Sesbania grandiflora subjected to metal stress induced by chelator. The reduced GSH levels in the present study could be attributed to the fact that, the reduced stress levels has limited the accumulation of GSH inside the plant due to NO activity.

\section{Conclusion}

The present study concludes that exogenous nitric oxide supply ameliorates the $\mathrm{Cr}$ toxicity in the presence of chelator EDTA. Nitric oxide also helped in ameliorating oxidative stress by decreasing the antioxidant levels in response to increasing metal and chelator concentration. Hence SNP when supplemented to heavy metal accumulating plants will reduce the stress levels in plants. Further studies are required to elucidate the changes in molecular levels, to identify the isoenzymes or proteins that are involved in mediating the ameliorating action of NO.

Acknowledgements. The authors would like to thank the VIT management for the constant support provided during the entire period of study.

\section{REFERENCES}

[1] Alloway, B. J. (1995): Soil Processes and the Behavior of Metals. - In: Alloway, B. J. (ed.) Heavy Metals in Soils. Blackie and Sons Limited, Glasgow, pp. 1-52.

[2] Azmat, R., Khanum, R. (2005a): Effect of chromium on uptakes of minerals in bean plant. - Pak J Biolo Sci 8: 281-283. 
[3] Baek, K. H., Skinner, D. Z. (2003): Alteration of antioxidant enzyme gene expression during cold acclimation of near-isogenic wheat lines. - Plant Science 165: 1221-1227.

[4] Bakiyaraj, R., Mahakavi, T., Baskaran, L. (2014): Chromium toxicity in Sesbania sesban (L.) Merr. - International Letters of Natural Sciences 4: 65-75.

[5] Beauchamp, C., Fridovich, I. (1971): Superoxide dismutase: improved assays and an assay applicable to acrylamide gels. - Anal Biochem 44: 276-287.

[6] Beyer, W. F., Fridovich, I. (1987): Assaying for superoxide dismutase activity: some large consequences of minor changes in conditions. - Analytical Biochemistry 161: 559566.

[7] Candan, N., Tarhan, L. (2003): The correlation between antioxidant enzyme activities and lipid peroxidation levels in Mentha pulegium organs grown in $\mathrm{Ca}^{2+}, \mathrm{Mg}^{2+}, \mathrm{Cu}^{2+}, \mathrm{Zn}^{2+}$ and $\mathrm{Mn}^{2+}$ stress conditions. - Plant Science 165: 769-776.

[8] Carlos, G. M., Lorenzo, L. (2001): Nitric oxide induces stomatal closure and the enhances adaptive plant responses against drought stress. - Plant Physiology 126: 11961204.

[9] Caro, A., Puntarulo, S. (1998): Nitric oxide decreases superoxide anion generation by microsomes from soybean embryonic axes. - Physiologia Plantarum 104: 357-364.

[10] Chalapathi Rao, A. S. V., Reddy, A. R. (2008): Glutathione Reductase: A Putative Redox Regulatory System in Plant Cells. - In: Khan, N. A., Singh, S., Umar, S. (eds.) Sulfur Assimilation and Abiotic Stresses in Plants. Springer, Netherlands, pp. 111-147.

[11] Cobbett, C. S. (2000): Phytochelatins and their roles in heavy metal detoxification. Plant Physiology 123: 825-832.

[12] Cobbett, C., Goldsbrough, P. (2002): Phytochelatins and metallothioneins: roles in heavy metal detoxification and homeostasis. - Annual Review of Plant Biology 53: 159-182.

[13] Dalurzo, H. C., Sandalio, L. M., Gómez, M., Del Río, L. A. (1996): Effect of Cadmium on the Growth and Oxidative Metabolism of Pea Plants. - In: Puig-Parellada, P., Mitjavila, M. T. (eds.) VII Biennial Meeting of the International Society for Free Radical Research. Abstracts Book. University of Barcelona, Barcelona.

[14] Delledonne, M., Xia, Y., Dixon, R. A., Lamb, C. (1998): Nitric oxide functions as a signal in plant disease resistance. - Nature 394: 585-588.

[15] Dhir, B., Sharmila, P., Saradhi, P. P., Nasim, S. A. (2009): Physiological and antioxidant responses of Salvinia natans exposed to chromium-rich wastewater. - Ecotoxicology and Environmental Safety 72: 1790-1797.

[16] Diels, L., Vander Lelie, N., Bastiaens, L. (2002): New development in treatment of heavy metal contaminated soils. - Reviews in Environmental Science and Biotechnology 1: 7582.

[17] Diwan, H., Ahmad, A., Iqbal, M. (2008): Genotypic variation in phytoremediation potential of Indian mustard for chromium. - Environmental Management 41: 734-741.

[18] Diwan, H., Ahmad, A., Iqbal, M. (2009): Chromium-induced modulation in the antioxidant defense system during phenological growth stages of Indian mustard. International Journal of Phytoremediation 12: 142-158.

[19] Diwan, H., Khan, I., Ahmad, A., Iqbal, M. (2010): Induction of phytochelatins and antioxidant defence system in Brassica juncea and Vigna radiata in response to chromium treatments. - Plant Growth Regulation 61: 97-107.

[20] Diwan, H., Ahmad, A., Iqbal, M. (2012): Chromium-induced alterations in photosynthesis and associated attributes in Indian mustard. - Journal of Environmental Biology 33: 239-244.

[21] Dong, Y., Xu, L., Wang, Q., Fan, Z., Kong, J., Bai, X. (2014): Effects of exogenous nitric oxide on photosynthesis, antioxidative ability, and mineral element contents of perennial ryegrass under copper stress. - Journal of Plant Interactions 9: 402-411.

[22] Ferreira, L. C., Cataneo, A. C., Remaeh, L. M. R., Corniani, N., Fumis, T. D. F., Souza, Y. A. D., Scavroni, J., Soares, B. J. A. (2010): Nitric oxide reduces oxidative stress 
generated by lactofen in soybean plants. - Pesticide Biochemistry and Physiology 97: 4754.

[23] Foyer, C. H., Noctor, G. (2005): Redox homeostasis and antioxidant signaling: a metabolic interface between stress perception and physiological responses. - Plant Cell 17: 1866-1875.

[24] Garba, S. T., Sunday, A., Manji, H., Tsaware, J (2012b): Ethylene diaminetetra acetate (EDTA)-assisted phytoremediation of heavy metal contaminated soil by Eleusine indica L. Gearth. - Journal of Environmental Chemistry and Ecotoxicology 4: 103-109.

[25] Gill, S. S., Tuteja, N. (2010): Reactive oxygen species and antioxidant machinery in abiotic stress tolerance in crop plants. - Plant Physiol Biochem 48: 909-930.

[26] Hasanuzzaman, M., Nahar, K., Alam, M. M., Fujita, M. (2012): Exogenous nitric oxide alleviates high temperature induced oxidative stress in wheat (Triticum aestivum L.) seedlings by modulating the antioxidant defense and glyoxalase system. - Australian Journal of Crop Science 6: 1314-1323.

[27] Hasanuzzaman, M., Nahar, K., Anee, T. I., Fujita, M. (2017): Glutathione in plants: biosynthesis and physiological role in environmental stress tolerance - Physiol Mol Biol Plants 23(2): 249-268.

[28] Hiner, A. N. P., Rodríguez-López, J. N., Arnao, M. B., Raven, E. L., García-Cánovas, F., Acosta, M. (2000): Kinetic study of the inactivation of ascorbate peroxidase by hydrogen peroxide. - Biochem J 348: 321-328.

[29] Hung, K. T., Kao, C. H. (2003): Nitric oxide counteracts the senescence of rice leaves induced by abscisic acid. - Journal of Plant Physiology 160: 871-879.

[30] Israr, M., Sahi, S. V., Jain, J. (2006): Cadmium accumulation and antioxidative responses in the Sesbania drumondiiallus. - Arch Environ Cont Toxicol 50: 121-127.

[31] Jadia, C. D., Fulekar, M. K. (2009): Phytoremediation of heavy metals: Recent techniques. - African Journal of Biotechnology 8: 921-928.

[32] Karuppanapandian, T., Sinha, P. B., Haniya, A. M. K., Mamoharan, K. (2006a): Differential antioxidative responses of ascorbate-glutathione cycle enzymes and metabolites to chromium stress in green gram (Vigna radiata L. Wilczek) leaves. Journal of Plant Biology 49: 440-447.

[33] Kaur, G., Singh, H. P., Batish, D. R., Mahajan, P., Kohli, R. K., Rishi, V. (2015): Exogenous nitric oxide $(\mathrm{NO})$ interferes with lead $(\mathrm{Pb})$-induced toxicity by Detoxifying reactive oxygen species in hydroponically grown wheat (Triticum aestivum) roots. - PloS One 10: 1-18.

[34] Laspina, N. V., Groppa, M. D., Tomaro, M. L., Benavides, M. P. (2005): Nitric oxide protects sunflower leaves against Cd-induced oxidative stress. - Plant Science 169: 323330.

[35] Lestan, D., Luo, C. L., Li, X, D. (2008): The use of chelating agents in the remediation of metal contaminated soils: a review. - Environmental Pollution 153: 3-13.

[36] Luck, H. (1974): Catalase. - In: Begmeyer, J., Garbi, M. (eds.) Methods of Enzymatic Analysis. Vol II. Academic Press, New York, pp.895-897.

[37] Luna, C. M., Gonzalez, C. A., Trippi, V. S. (1994): Oxidative damage caused by an excess of copper in oat leaves. - Plant Cell Physiology 35: 11-15.

[38] Martinez, G. R., Di Mascio, P., Bonini, M. G., Augusto, O., Briviba, K., Sies, H., Maurer, P., Rothlisberger, U., Herold, S., Koppenol, W. H. (2000): Peroxynitrite does not decompose to singlet oxygen $\left({ }^{1} \mathrm{O}_{2}\right)$ and nitroxyl $\left(\mathrm{NO}^{-}\right)$. - Proceedings of the National Academy of Sciences 97: 10307-10312.

[39] Mates, J. M. (2000): Effects of antioxidant enzymes in the molecular control of reactive oxygen species toxicology. - Toxicology 153: 83-104.

[40] Maiti, S., Ghosh, N., Mandal, C., Das, K., Dey, N., Adak, M. K. (2012): Responses of the maize plant to chromium stress with reference to antioxidation activity. - Brazilian Journal of Plant Physiology 24: 203-212. 
[41] Metwally, A., Safronova, A. B., Dietz, K. J. (2005): Genotypic variation of the response to cadmium toxicity in Pisum sativum L. - J Exp Bot 56: 167-178.

[42] Mittler, R. (2002): Oxidative stress, antioxidants and stress tolerance. - Trends Plant Science 7: 405-410.

[43] Mittova, V., Theodoulou, F. L., Kiddle, G., Gomez, L., Volokita, M., Tal, M., Foyer, C. M., Guy, M. (2003): Coordinate induction of glutathione biosynthesis and glutathione metabolizing enzymes is correlated with salt tolerance in tomato. - FEBS Letter 554: 417-421.

[44] Molina, A. S., Nievas, C., Chaca, M. V. P., Garibotto, F., Gonza'lez, U., Marsa, S. M., Luna, C., Gime'nez, M. S., Zirulnik, F. (2008): Cadmium-induced oxidative damage and antioxidative defense mecha-nisms in Vigna mungo L. - Plant Growth Regul 56: 285295.

[45] Morita, S., Kaminaka, H., Masumura, T., Tanaka, K. (1999): Induction of rice cytosolic ascorbate peroxidase mRNA by oxidative stress; the involvement of hydrogen peroxide in oxidative stress signalling. - Plant and Cell Physiology 40: 417-422.

[46] Mullineaux, P., Rausch, T. (2005): Glutathione, photosynthesis and the redox regulation of stress-responsive gene expression. - Photosynthesis Research 86: 459-474.

[47] Nakano, Y., Asada, K. (1981): Hydrogen peroxide is scavenged by ascorbate specific peroxidase in spinach chloroplasts. - Plant and Cell Physiology 22: 867-880.

[48] Nehnevajova, E., Lyubenova, L., Herzig, R., Schröder, P., Schwitzguebel, J. P., Schmulling, T. (2012): Metal accumulation and response of antioxidant enzymes in seedlings and adult sunflower mutants with improved metal removal traits on a metal contaminated soil. - Environmental and Experimental Botany 76: 39-48.

[49] Neill, S. J., Desikan, R., Hancock, J. T. (2003): Nitric oxide signalling in plants. - New Phytologist 159: 11-35.

[50] Oberbacher, M. F., Vines, H. M. (1963): Spectrophotometric assay of ascorbic acid Oxidase. - Nature 197: 1203-1204.

[51] Panda, S. K. (2007): Chromium-mediated oxidative stress and ultrastructural changes in root cells of developing rice seedlings. - Journal of Plant Physiology 164: 1419-1428.

[52] Pietrini, F., Iannelli, M. A., Pasqualini, S., Massacci, A. (2003): Interaction of cadmium with glutathione and photosynthesis in developing leaves and chloroplasts of Phragmites australis (Cav.) Trin. ex Steudel. - Plant Physiology 133: 829-837.

[53] Quartacci, M. F., Argilla, A., Baker, A. J. M., Navari-Izzo, F. (2006): Phytoextraction of metals from a multiply contaminated soil by Indian mustard. - Chemosphere 63: 918925.

[54] Qureshi, M. I., Israr, M., Abdin, M. Z., Iqbal, M. (2005): Responses of Artemisia annua L. to lead and salt-induced oxidative stress. - Environ Exp Bot 53: 185-193.

[55] Qureshi, M. I., Abdin, M. Z., Qadir, S., Iqbal, M. (2007): Lead-induced oxidative stress and metabolic alterations in Cassia angustifolia Vahl. - Biologia Plantarum 51: 121-128.

[56] Rao, M. V., Paliyath, G., Ormrod, D. P. (1996): Ultraviolet-B-and ozone-induced biochemical changes in antioxidant enzymes of Arabidopsis thaliana. - Plant Physiology 110: 125-136.

[57] Rai, V., Vajpayee, P., Singh, S. N., Mehrotra, S. (2004): Effect of chromium accumulation on photosynthetic pigments, oxidative stress defense system, nitrate reduction, proline level and eugenol content of Ocimum tenuiflorum L. - Plant Science 167: 1159-1169.

[58] Rai, R. K., Srivastava, M. K., Khare, A. K., Kishor, R., Shrivastava, A. K. (2006): Oxidative stress response and glutathione linked enzymes in relation to growth of sugarcane plants exposed to hexavalent chromium. - Sugar Tech 8: 116-123.

[59] Reddy, A. R., Raghavendra, A. S. (2006): Photo Oxidative Stress. - In: Madhava Rao, K. V., Raghavendra, A. S., Reddy, K. J. (ed.) Physiology and Molecular Biology of Stress Tolerance in Plants. Springer, Netherlands, pp. 157-186. 
[60] Romero-Puertas, M. C., Corpas, F. J., Sandalio, L. M., Leterrier, M., Rodriguez-Serrano, M., del Rio, L. A., Palma, J. M. (2006): Glutathione Reductase from pea leaves: response to abiotic stress and characterization of the peroxisomal isozyme. - New Phytol 170: 4352.

[61] Sanita di Toppi, L., Fossati, F., Musetti, R., Mikerezi, I., Favali, M. A. (2002): Effect of hexavalent chromium on maize, tomato, and cauli-flower plants. - J Plant Nutr 25: 701717.

[62] Schmidt, U. (2003): Enhancing phytoextraction: the effect of chemical soil manipulation on mobility, plant accumulation, and leaching of heavy metals. - J Environ Qual 32: 1939-1954.

[63] Shanker, A. K., Djanaguiraman, M., Sudhagar, R., Chandrashekar, C. N. and Pathmanabhan, G. (2004): Differential antioxidative response of ascorbate glutathione pathway enzymes and metabolites to chromium speciation stress in green gram (Vigna radiata (L.) R. Wilczek. cv $\mathrm{CO}_{4}$ ) roots. - Plant Science 166: 1035-1043.

[64] Shanker, A. K., Cervantes, C., Loza-Tavera, H., Avudainayagam, S. (2005): Chromium toxicity in plants. - Environment International 31: 739-753.

[65] Sharma, D. C., Sharma, C. P. (1996): Chromium uptake and toxicity effects on growth and metabolic activities in wheat, Triticum aestivum L. cv. UP 2003. - Indian Journal of Experimental Biology 34: 689-691.

[66] Shigeoka, S., Ishikawa, T., Tamoi, M., Miyagawa, Y., Takeda, T., Yabuta, Y., Yoshimura, K. (2002): Regulation and function of ascorbate peroxidase isoenzymes. Journal of Experimental Botany 53: 1305-1319.

[67] Sinam, G., Sinha, S., Mallick, S. (2011): Effect of chromium on accumulation and antioxidants in Cucumis utillissimus L. Response under enhanced bioavailability condition. - Journal of Environmental Sciences 23: 506-512.

[68] Singh, A., Agrawal, S. B., Rathore, D. (2005): Amelioration of Indian urban air pollution phytotoxicity in Beta vulgaris L. by modifying NPK nutrients. - Environmental Pollution 134: 385-395.

[69] Singh, H. P., Batish, D. R., Kaur, G., Arora, K., Kohli, R. K. (2008): Nitric oxide (as sodium nitroprusside) supplementation ameliorates $\mathrm{Cd}$ toxicity in hydroponically grown wheat roots. - Environmental and Experimental Botany 63: 158-167.

[70] Smirnoff, N. (1996): The Function and Metabolism of Ascorbic Acid in Plants. - Annals of Botany 78: 661-669.

[71] Smirnoff, N. (2000): Ascorbic acid: metabolism and functions of a multi-facetted molecule. - current Opinion in Plant Biology 3: 229-235.

[72] Sun, Q., Ye, Z. H., Wang, X. R., Wong, M. H. (2007): Cadmium hyperaccumulation leads to an increase of glutathione rather than phytochelatins in the cadmium hyperaccumulator Sedum alfredii. - Journal of Plant Physiology 164: 1489-1498.

[73] Talukdar, D. (2012b): Ascorbate deficient semi-dwarf asfL1 mutant of Lathyrus sativus exhibits alterations in antioxidant defense. - Biologia Plantarum 56: 675-682.

[74] Thounaojam, T. C., Panda, P., Mazumdar, P., Kumar, D., Sharma, G. D., Sahoo, L. Sanjib, P. (2012): Excess copper induced oxidative stress and response of antioxidants in rice. - Plant Physiology and Biochemistry 53: 33-39.

[75] Tukendorf, A., Rauser, W. E. (1990): Changes in glutathione and phytochelatins in roots of maize seedlings exposed to cadmium. - Plant Sci 70: 155-166.

[76] Uchida, A., Jagendorf, A. T., Hibino, T., Takabe, T., Takabe, T. (2002): Effects of hydrogen peroxide and nitric oxide on both salt and heat stress tolerance in rice. - Plant Science 163: 515-523.

[77] Vijendra, P. D., Huchappa, K. M., Lingappa, R., Basappa, G., Jayanna, S. G., Kumar, V. (2016): Physiological and biochemical changes in moth bean (Vigna aconitifolia L.) under cadmium stress. - Journal of Botany 2016: 1-13. 


$$
\text { - } 3291 \text { - }
$$

[78] Yadav, S. K., Dhote, M., Kumar, P., Sharma, J., Chakrabarti, T., Juwarkar, A. A. (2010): Differential antioxidative enzyme responses of Jatropha curcas L. to chromium stress. Journal of Hazardous Materials 180: 609-615.

[79] Zulfiqar, A., Paulose, B., Chhikara, S., Dhankher, O. P. (2011): Identifying genes and gene networks involved in chromium metabolism and detoxification in Crambe abyssinica. - Environmental Pollution 159: 3123-3128. 